\title{
Recent Advances in Pharmacological and Non-Pharmacological Strategies of Cardioprotection
}

\author{
Afonso Caricati-Neto *, Paolo Ruggero Errante and Francisco Sandro Menezes-Rodrigues \\ Department of Pharmacology, Laboratory of Autonomic and Cardiovascular Pharmacology, Escola Paulista de \\ Medicina-Universidade Federal de São Paulo (UNIFESP), Vila Clementino, São Paulo-SP 04039-032, Brazil \\ * Correspondence: caricatineto@gmail.com
}

Received: 3 June 2019; Accepted: 30 July 2019; Published: 16 August 2019

\begin{abstract}
Ischemic heart diseases (IHD) are the leading cause of death worldwide. Although the principal form of treatment of IHD is myocardial reperfusion, the recovery of coronary blood flow after ischemia can cause severe and fatal cardiac dysfunctions, mainly due to the abrupt entry of oxygen and ionic deregulation in cardiac cells. The ability of these cells to protect themselves against injury including ischemia and reperfusion $(\mathrm{I} / \mathrm{R})$, has been termed "cardioprotection". This protective response can be stimulated by pharmacological agents (adenosine, catecholamines and others) and non-pharmacological procedures (conditioning, hypoxia and others). Several intracellular signaling pathways mediated by chemical messengers (enzymes, protein kinases, transcription factors and others) and cytoplasmic organelles (mitochondria, sarcoplasmic reticulum, nucleus and sarcolemma) are involved in cardioprotective responses. Therefore, advancement in understanding the cellular and molecular mechanisms involved in the cardioprotective response can lead to the development of new pharmacological and non-pharmacological strategies for cardioprotection, thus contributing to increasing the efficacy of IHD treatment. In this work, we analyze the recent advances in pharmacological and non-pharmacological strategies of cardioprotection.
\end{abstract}

Keywords: cardioprotection; ischemic conditioning; cardioprotective drugs; cardiac ischemia and reperfusion

\section{Introduction}

Ischemic heart diseases (IHD) are the main cause of death in developed and non-developed countries [1]. Although the principal form of treatment of IHD is myocardial reperfusion, the recovery of coronary blood flow after ischemia can cause cardiac dysfunctions, mainly due to the abrupt entry of oxygen and ionic deregulation in cardiac cells [2]. These dysfunctions produced by ischemia and reperfusion $(\mathrm{I} / \mathrm{R})$ injury may result in the collapse of myocardial function, increasing the incidence of cardiac arrhythmias and causing death of cardiac cells, due mainly to cytosolic $\mathrm{Ca}^{2+}$ overload, a deficit in ATP production by mitochondria and the formation of excessive free radicals [3]. As this cardiac collapse can be fatal, several non-pharmacological and pharmacological cardioprotective strategies have been proposed to protect the myocardium of lesions caused by I/R injury and increase the effectiveness of IHD treatment. In this work, we analyze the recent advances in non-pharmacological and pharmacological strategies for cardioprotection.

\subsection{Cellular Signalling Involved in the Regulation of Cardiac Function}

The mechanical activity of the heart is induced by electrical stimulus generated by the sinoatrial node (SA) and propagated by the atrioventricular node (AV) and His-Purkinje fibers to ventricles [4]. The cardiac electrical activity defines the format and the time of propagation of electrical signals detected by electrocardiogram (ECG) [4]. The electrical activity resulting from the propagation of 
action potential (AP) on the plasma membrane of cardiac cells reaches the $\mathrm{T}$ tubules stimulating the $\mathrm{Ca}^{2+}$ influx through L-type voltage-dependent $\mathrm{Ca}^{2+}$ channels (VDCC) [5]. The $\mathrm{Ca}^{2+}$ influx stimulates the $\mathrm{Ca}^{2+}$ release from sarcoplasmic reticulum (SR) through the activation of $\mathrm{Ca}^{2+}$ channels regulated by the ryanodine receptors (RyR) [5]. This $\mathrm{Ca}^{2+}$-release $\mathrm{Ca}^{2+}$-induced (CICR) mechanism transiently amplifies the cytosolic $\mathrm{Ca}^{2+}$ concentration $\left(\left[\mathrm{Ca}^{2+}\right] \mathrm{c}\right)$, which stimulates the activity of contractile proteins, unleashing the contraction of cardiac cells $[5,6]$. The free $\mathrm{Ca}^{2+}$ in the cytosol binds to troponin $\mathrm{C}$ $(\mathrm{TnC})$, which favors the interaction of these proteins with troponin I (TnI), causing TnI to shift from the active site of actin, allowing the displacement of tropomyosin $\mathrm{T}(\mathrm{TmT})$ and troponin $\mathrm{T}(\mathrm{TnT})$, the myosin-actin interaction and the contraction of cardiac cells (systole) $[6,7]$. The increase of $\left[\mathrm{Ca}^{2+}\right] \mathrm{c}$ during the contraction of cardiac cells is restored to basal levels (resting) by $\mathrm{Ca}^{2+}$ sequestration SR and other cytoplasmic organelles, and $\mathrm{Ca}^{2+}$ extrusion by ionic transporters located in plasma membrane of cardiac cells [5]. This reduction in $\left[\mathrm{Ca}^{2+}\right]$ c promotes the relaxation of cardiac cells (diastole) $[5,8]$.

The SR has an important role in the regulating contraction-relaxation cycle in cardiac cells, acting as cytoplasmic reservoir of $\mathrm{Ca}^{2+}[9]$. SR sequestrates the $\mathrm{Ca}^{2+}$ from cytosol by ATP-dependent $\mathrm{Ca}^{2+}$-ATPase (SERCA), especially by SERCA2 $\mathrm{A}$ [9]. The excess of $\mathrm{Ca}^{2+}$ in the cytosol is regulated by two $\mathrm{Ca}^{2+}$ extrusion mechanisms located in plasma membrane: the $\mathrm{Na}^{+} / \mathrm{Ca}^{2+}$ exchanger (NCX) and plasma membrane $\mathrm{Ca}^{2+}$-ATPase (PMCA) [5,9]. The NCX transports $\mathrm{Ca}^{2+}$ from cytosol to extracellular medium (reverse mode) or from extracellular medium to cytosol (reverse mode) $[9,10]$. Thus, SERCA, NCX and PCMA play an important role in the contraction-relaxation cycle by finely regulating the $\left[\mathrm{Ca}^{2+}\right] \mathrm{c}$ in cardiac cells.

In addition to SR, mitochondria also participate in the cellular homeostasis of $\mathrm{Ca}^{2+}$ during transient elevations of $\left[\mathrm{Ca}^{2+}\right] \mathrm{c}$ in cardiac cells, contributing to the contraction-relaxation cycle [5]. The mitochondrial membranes are equipped with $\mathrm{Ca}^{2+}$ transporter proteins that regulate the $\mathrm{Ca}^{2+}$ influx and efflux in mitochondrial matrix, thus adjusting the $\mathrm{Ca}^{2+}$ concentration in mitochondrial matrix $\left(\left[\mathrm{Ca}^{2+}\right] \mathrm{m}\right)[11]$. In cardiac cells and other excitable cells, $\mathrm{Ca}^{2+}$ influx into mitochondria is mainly regulated by mitochondrial $\mathrm{Ca}^{2+}$ uniporter (MCU) [12], and its efflux is mainly regulated by mitochondrial $\mathrm{Na}^{+} / \mathrm{Ca}^{2+}$ exchanger (mNCX) $[13,14]$. Thus, the participation of mitochondria in $\mathrm{Ca}^{2+}$ homeostasis in cardiac cells has important implications in the cardiac cycle and contraction-relaxation process. Figure 1 illustrates the molecular mechanisms involved in cellular $\mathrm{Ca}^{2+}$ homeostasis in cardiac cells.

\subsection{Cardiac Dysfunctions Produced by Ischemia and Reperfusion}

The molecular mechanisms involved in regulation of $\left[\mathrm{Ca}^{2+}\right] \mathrm{c}$ in cardiac cells are responsible for fine control of the heart rate. Thus, changes in $\mathrm{Ca}^{2+}$ extrusion or buffering may precipitate the spontaneous release of $\mathrm{Ca}^{2+}$ from the SR, and generate triggered activity as the delayed after depolarization [15]. During ischemia, the deregulation in cellular $\mathrm{Ca}^{2+}$ homeostasis caused by inadequate functioning of $\mathrm{Ca}^{2+}$-ATPases results in cytosolic and mitochondrial $\mathrm{Ca}^{2+}$ overload, collapsing the mitochondrial function and ATP production [16]. During reperfusion, this $\mathrm{Ca}^{2+}$ overload is aggravated due to increased $\mathrm{Ca}^{2+}$ influx into cytosol through NCX activity and the increment in formation of free radicals [16]. The increment in the formation of free radicals causes oxidation of structural proteins and proteins involved in the respiratory chain, oxidation of pyridine nucleotides, changes in the permeability of internal mitochondrial membrane, decoupling of oxidative phosphorylation, and a collapse in ATP production by mitochondria [17]. Figure 2 illustrates the molecular mechanisms involved in cellular dysfunctions caused by ischemia followed by reperfusion (I/R) injury in cardiac cells. 


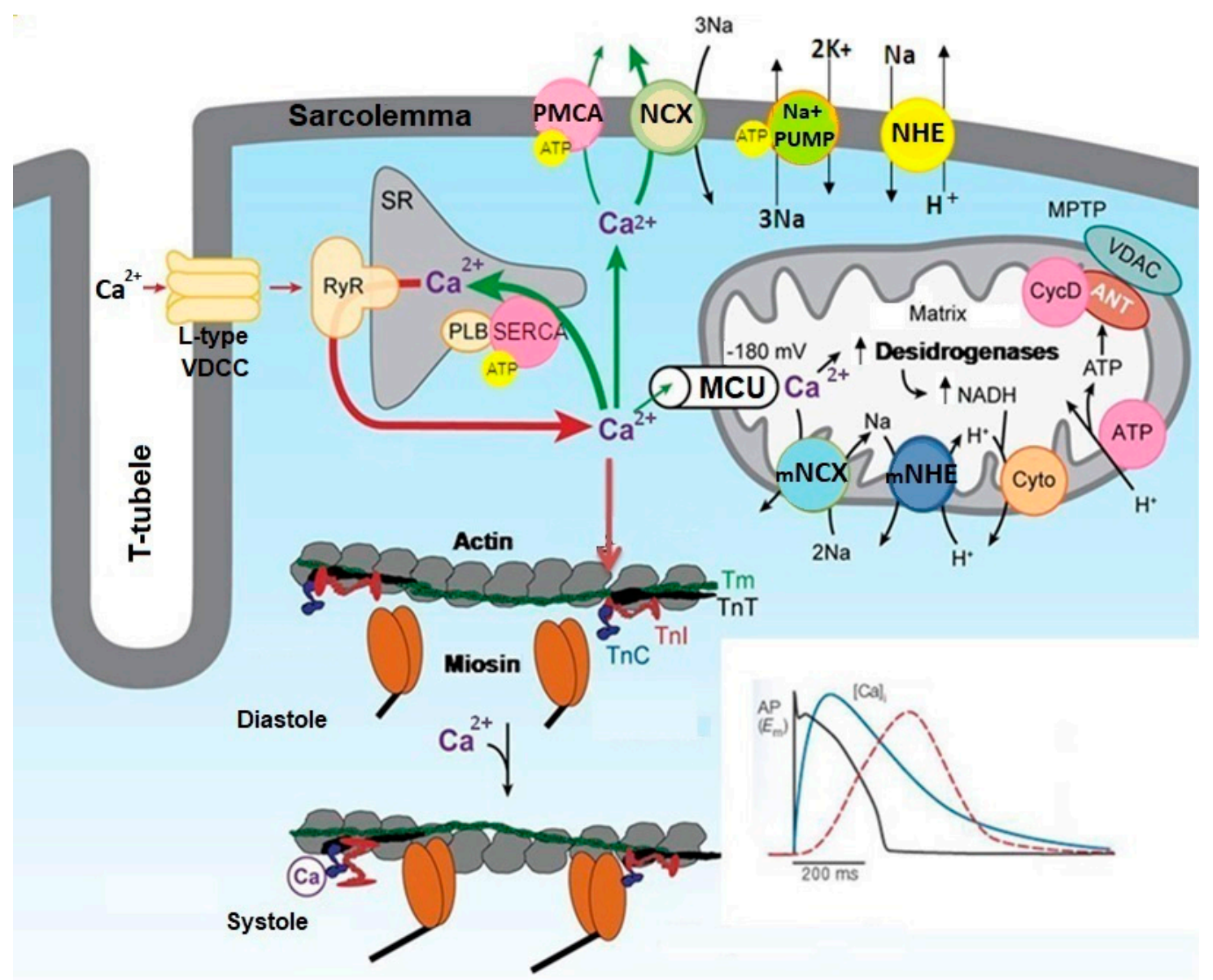

Figure 1. Molecular mechanisms involved in cellular $\mathrm{Ca}^{2+}$ homeostasis in cardiac cells. This figure illustrates that $\mathrm{Ca}^{2+}$ influx through L-type VDCC stimulates the release of $\mathrm{Ca}^{2+}$ from the SR through the RyR, increasing the cytosolic $\mathrm{Ca}^{2+}$ concentration $\left(\left[\mathrm{Ca}^{2+}\right] \mathrm{c}\right) . \mathrm{Ca}^{2+}$ binds to $\mathrm{TnC}$ and promotes the interaction of TnC with TnI, causing TnI to move from the active site of the actin, allowing the displacement of $\mathrm{TmT}$ and $\mathrm{TnT}$, and muscle contraction (systole). This increase in $\left[\mathrm{Ca}^{2+}\right] \mathrm{c}$ increments the $\mathrm{Ca}^{2+}$ influx into mitochondria via MCU, stimulating the synthesis of ATP. The increase of $\left[\mathrm{Ca}^{2+}\right] \mathrm{c}$ is restored to basal levels (resting) by $\mathrm{Ca}^{2+}$ sequestration SR via SERCA and $\mathrm{Ca}^{2+}$ extrusion via PMCA and NCX, and this reduction in $\left[\mathrm{Ca}^{2+}\right] \mathrm{c}$ promotes the relaxation of cardiac cells (diastole). The inset represents the electromechanical coupling in the cardiac cell. The initial wave produces a transient increase in cytosolic $\mathrm{Ca}^{2+}$ concentration followed by cell contraction. Once the electrical stimulus has finished, the cytosolic $\mathrm{Ca}^{2+}$ concentration returns to baseline by the action of mechanisms involved in $\mathrm{Ca}^{2+}$ sequestration and extrusion, allowing relaxation of cardiac cells (adapted from Bers, 2008 [5]). 


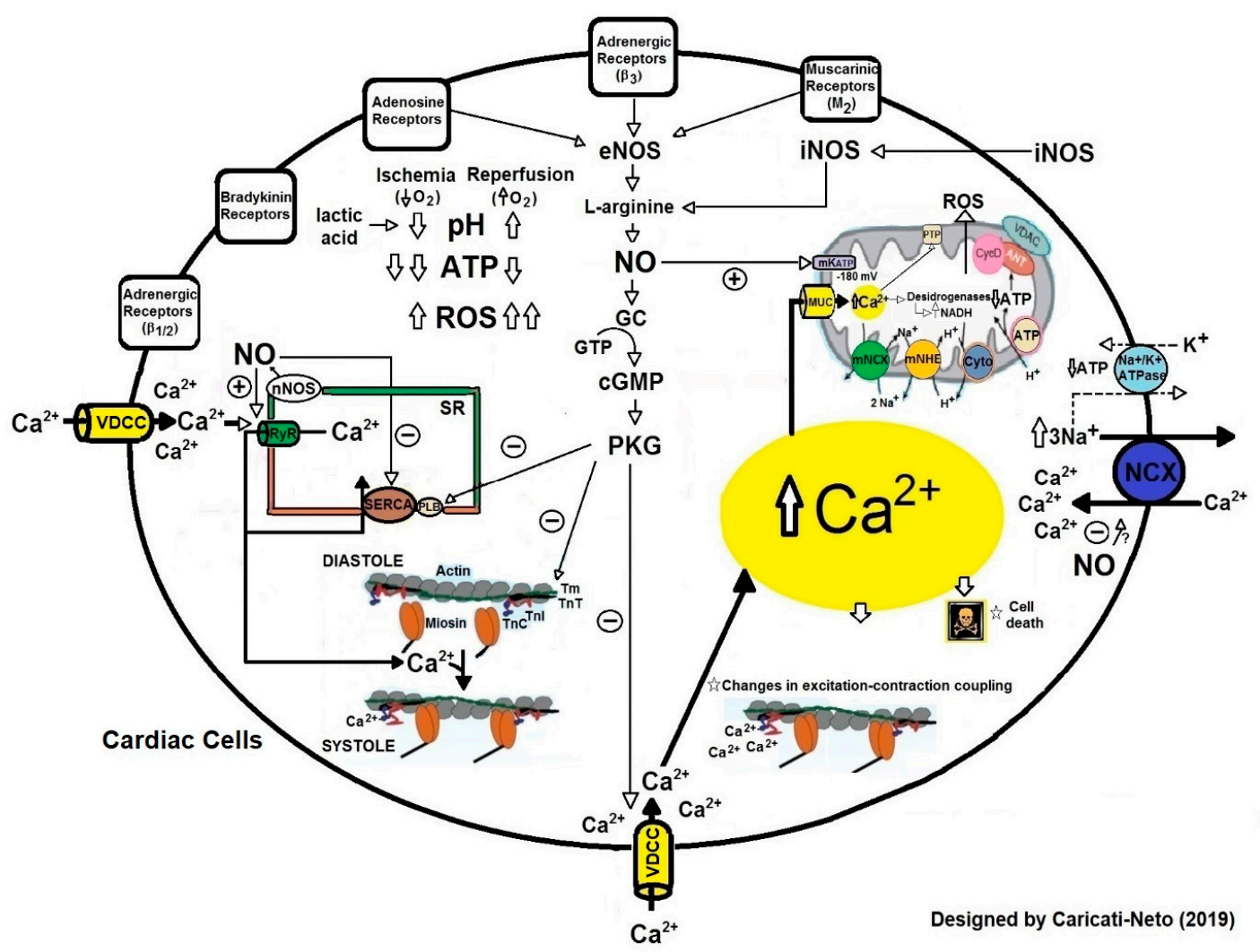

Figure 2. Molecular mechanisms involved in cellular dysfunctions caused by ischemia and reperfusion (I/R) injury in cardiac cells. During ischemia, intracellular accumulation of inorganic phosphate, lactate and $\mathrm{H}$ reduce intracellular $\mathrm{pH}$, which increases NHE activity. ATP deficiency reduces the activity of ATP-dependent ion transport proteins, such as $\mathrm{Na}^{+} / \mathrm{K}^{+}$-ATPase, PMCA and SERCA, favoring $\mathrm{Na}^{+}$and $\mathrm{Ca}^{2+}$ accumulation in the cytosol, which interferes with the plasma membrane NCX activity, worsening the cytosolic $\mathrm{Ca}^{2+}$ overload. The $\mathrm{Ca}^{2+}$ accumulation in cytosol compromises the mitochondrial membrane potential, leading to increased mitochondrial $\mathrm{Ca}^{2+}$ uptake through the $\mathrm{MCU}$, generating mitochondrial $\mathrm{Ca}^{2+}$ overload. This $\mathrm{Ca}^{2+}$ overload collapses mitochondrial function, altering ATP production. The cytosolic and mitochondrial $\mathrm{Ca}^{2+}$ overload alters excitation-contraction coupling, and thus increasing the incidence of cardiac arrhythmias. In reperfusion, the cytosolic and mitochondrial $\mathrm{Ca}^{2+}$ initiated in ischemia, additionally compromise oxidative phosphorylation and produce increment in the permeability of the internal mitochondrial membrane. This results in the production of free radicals that stimulate the opening of transition pores of mitochondrial permeability, releasing cytochrome $\mathrm{C}$, which activates the apoptotic cascade. Increased production of free radicals causes structural damage and aggravates the cytosolic $\mathrm{Ca}^{2+}$ overload, causing severe arrhythmias and cardiac collapse.

\section{Cardioprotective Strategies Against Myocardial Lesions Caused by I/R Injury}

Although the reperfusion is the main treatment of acute myocardial infarction, this process may aggravate the myocardial lesions caused during ischemia, generating severe cardiac collapse [18,19]. As this collapse can be fatal, several non-pharmacological and pharmacological cardioprotective strategies have been proposed to protect the myocardium of lesions caused by I/R injury and increase the effectiveness of IHD treatment. In this paper, we analyze the recent advances in non-pharmacological and pharmacological strategies of cardioprotection.

\subsection{Non-Pharmacological Strategies for Cardioprotection}

A few decades ago, it was discovered that cardiac cells possess intracellular signaling pathways that, when stimulated, protect these cells against the damage caused by I/R injury. This ability of cardiac cells 
to protect themselves against injury has been termed "cardioprotection" [20]. Cardioprotection can be stimulated by several non-pharmacological procedures, including ischemic pre- and postconditioning applied directly in myocardium [20]. The conditioning phenomena exert powerful cardioprotection but still use $\mathrm{I} / \mathrm{R}$, which as such is injurious, and in pre- and postconditioning, there is also the risk of atherosclerotic lesions and coronary microembolization, particularly in ischemic postconditioning [20]. Thus, a better understanding of the signal transduction involved in conditioning phenomena may help to stimulate the cardioprotective response without the coronary lesions and inevitable myocardial injury caused by $\mathrm{I} / \mathrm{R}$, and additionally, may help to account for and attenuate interference from confounding risk factors, comorbidities, and comedications [20]. Cardioprotective response also can be stimulated by brief cycles of I/R at a remote non-cardiac site (remote ischemic conditioning) [20]. Cardioprotection stimulated by remote ischemic conditioning has been established in many experimental studies and successfully translated to patients [20]. This cardioprotective strategy which is characterized by a systemic response, efficiently reduces the infarct size and improves the prognosis for reperfused myocardial infarction [20].

In addition, cardioprotective response can also be stimulated by exposure to different degrees of hypoxia (as well as by a subhypoxic drop in oxygen tension), and by both hyper- and hypothermia [20]. The cardioprotective effect of hypothermia has been well demonstrated in animal models of acute myocardial infarction [20]. This cardioprotective strategy has been associated with prevention of the no-reflow phenomenon and long-term improvement in terms of left ventricular remodeling and performance [20].

Interestingly, recent evidence indicates that some physiological and pathological conditions, such as the regular practice of physical exercise and sympathetic hyperactivity, can potentially stimulate the cardioprotective response. Although the signal transduction involved in this response is still not known, these conditions can virtually stimulate the same cellular signaling pathways involved in conditioning. In this paper, we analyze the cardioprotection stimulated by ischemic pre- and post-conditioning, remote ischemic conditioning, hypothermia, regular practice of physical exercises and sympathetic hyperactivity.

\subsubsection{Cardioprotection Stimulated by Ischemic Preconditioning}

Ischemic preconditioning is when cardioprotective response is stimulated by brief episodes of $\mathrm{I} / \mathrm{R}$ applied prior to sustained metabolic stress (including ischemia and I/R) $[1,20]$. This procedure reduces the number of premature ventricular beats, and the incidence and duration of ventricular tachycardia and fibrillation [18-25]. Ischemic preconditioning activates cellular survival pathways mediated by phosphatidyl inositol 3'-hydroxy kinase (PI3K)/protein kinase B (Akt) and increases cytosolic levels of nitric oxide (NO) in cardiac cells, stimulating cardioprotection (see Figure 2) [20]. During ischemic preconditioning, mitochondrial ATP-dependent $\mathrm{K}^{+}$channels $\left(\mathrm{mK}_{\mathrm{ATP}}\right)$ located on the inner mitochondrial membrane of cardiac cells are activated, increasing mitochondrial matrix volume, fatty acid oxidation, and production of free radicals $[26,27]$. These channels control the mitochondrial volume through the $\mathrm{K}^{+}$fluxes and oxidation of fatty acids involved in the cellular response stimulated by ischemic preconditioning $[26,27]$. The opening of $\mathrm{mK}_{\mathrm{ATP}}$ channels involves the epsilon isoform of protein kinase C (PKC $\varepsilon$ ) [26,27], impeding the hyperpolarization of inner mitochondrial membranes [28]. This avoids excessive mitochondrial $\mathrm{Ca}^{2+}$ accumulation, which prevents the prolonged opening of mitochondrial permeability transition pore (MPTP), and induces cytochrome $C$ release and caspases activation [28-31]. The activation of the $\mathrm{mK}_{\text {ATP }}$ channels stimulated by ischemic preconditioning is preceded by the activation of other kinases, such as tyrosine kinases and mitogen-activated protein kinases (MAPK), which activate the NO-inducible synthase (iNOS), and NO synthesis. NO activates intracellular signaling mediated by guanylate cyclase (GC)/cyclic guanosine monophosphate (cGMP)/protein kinase G (PKG) pathway and stimulates the opening of $\mathrm{mK}_{\mathrm{ATP}}$ decreasing mitochondrial $\mathrm{Ca}^{2+}$ overload and mitochondrial collapse in cardiac cells, thus inducing cardioprotection [32]. Our studies showed that ischemic preconditioning significantly 
reduced the incidence of severe arrhythmias and lethality caused by cardiac I/R injury mainly due to the attenuation of excitation-contraction decoupling resultant from the ionic imbalance in the cardiac cells [33].

The main advantages of ischemic preconditioning are that this process can be induced by ischemia directly in the heart or remotely, and can be programmed in the case of surgical interventions or angioplasty-situations in which the function of the heart is compromised [23-25]. Ischemic preconditioning has two periods of cardioprotective efficacy with different characteristics: (1) the first window of protection (early preconditioning) is more effective in reducing the size of the infarct, and (2) the second (late) protection window is more effective against "myocardial stunning" [23-25]. Figure 3 illustrates intracellular signaling involved in cardioprotective response stimulated by ischemic preconditioning in cardiac cells.

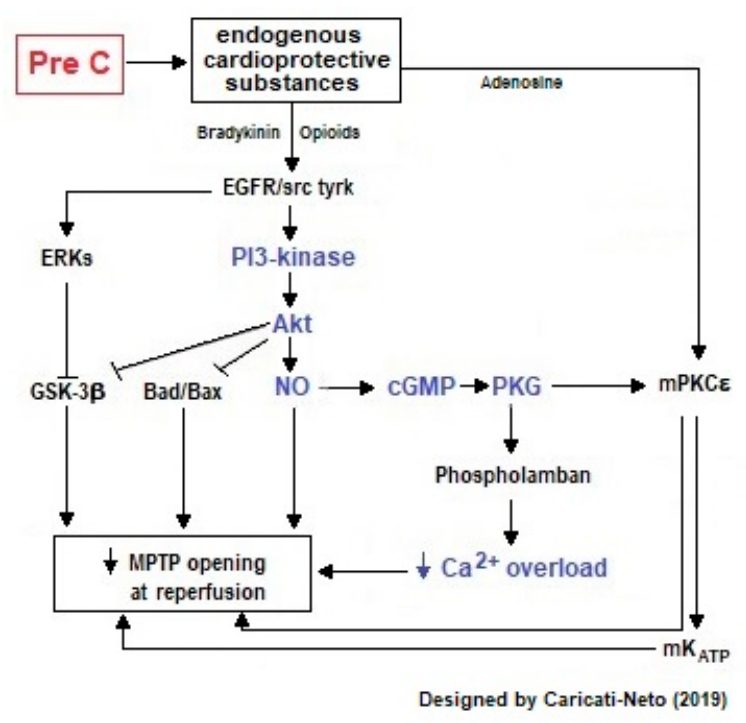

Figure 3. Intracellular signaling involved in cardioprotective response stimulated by ischemic preconditioning (PreC) in cardiac cells. This figure illustrates that PreC activates cellular survival pathways mediated by PI3K/Akt and increases cytosolic levels of NO in cardiac cells. NO activates intracellular signaling pathway mediated by GC/cGMP/PKG and stimulates the opening of $\mathrm{mK}_{\text {ATP }}$ by decreasing mitochondrial $\mathrm{Ca}^{2+}$ overload. These cellular responses attenuate cytosolic $\mathrm{Ca}^{2+}$ overload, reduce the formation of free radicals, prolonged opening of MPTP channels, and increase ATP production, attenuating excitation-contraction decoupling, and thus reducing the incidence of severe arrhythmias and cellular death. The arrows represent activation signal and " $\mathrm{T}$ " bars represent inhibition signal.

\subsubsection{Cardioprotection Stimulated by Ischemic Postconditioning}

Ischemic postconditioning is when cardioprotective response is stimulated by brief episodes of $\mathrm{I} / \mathrm{R}$ applied after the main insult $[1,20,33,34]$. This procedure reduces the size of the infarcted cardiac area to a level equivalent to ischemic preconditioning $[35,36]$. This cardioprotective response stimulated by ischemic postconditioning is associated with improved endothelial function, reduction in superoxide generation, and a reduction in apoptosis rate and microvascular lesions [34]. Cardioprotection stimulated by ischemic postconditioning is mainly mediated by activation of intracellular signaling pathways involved in the survival of cardiac cells [20]. The mechanisms by which ischemic postconditioning confers cardioprotection against cardiac $\mathrm{I} / \mathrm{R}$ injury resemble those of ischemic preconditioning; where adenosine has a cardioprotective effect conferred by ischemic postconditioning, and adenosine inhibitors may eradicate this effect. Other mechanisms include the participation of endothelial NO synthase (eNOS), NO, GC, $\mathrm{mK}_{\text {ATP }}$ channels and MPTP [34]. Thus, drugs that inhibit 
NO biosynthesis (Nw-nitro-L-arginine methyl ester, L-NAME) or blockade the cellular action of NO (GC inhibitors) reduce the cardioprotective effect triggered by ischemic postconditioning [37,38].

Ischemic postconditioning is more clinically applicable than ischemic preconditioning, since its application does not occur before an ischemic episode, but at the time of reperfusion [35,36]. In human studies, electrocardiographic parameters and ischemic myocardial perfusion were improved through ischemic postconditioning ( 2 cycles of 90 s separated by 3 and $5 \mathrm{~min}$ ) in patients who suffered acute myocardial infarction and who underwent reperfusion therapy [39]. Some studies showed that patients submitted to coronary angioplasty to treat acute myocardial infarction were submitted to ischemic postconditioning with 4 cycles of $\mathrm{I} / \mathrm{R}$ (1 min each) [40]. This procedure produced a reduction in serum levels of creatine kinase (CK), improvement of microvascular circulation and reduction in the infarct area size [40]. The main advantages of ischemic postconditioning are its applicability in patients who have suffered unpredictable acute myocardial infarction and the possibility of short-term treatment in the post-ischemic phase [35,36].

Studies in animal models of myocardial infarction showed that ischemic postconditioning improved myocardial metabolic recovery and increased myocardial salvage [41,42]. Our studies in animal models of cardiac $\mathrm{I} / \mathrm{R}$ injury indicate that ischemic postconditioning attenuates ionic imbalance in cardiac cells by reducing the cytosolic and mitochondrial $\mathrm{Ca}^{2+}$ overload, thus reducing excitation-contraction decoupling and incidence of severe arrhythmias and lethality caused by I/R injury [42]. Ischemic postconditioning also reduces the formation of free radicals, prolonged opening of MPTP, and ATP deficit production [41,42]. Our studies also indicate that the cardioprotection stimulated by ischemic postconditioning is less efficient than that induced by ischemic preconditioning [42]. In contrast to the beneficial effects observed in animal models, ischemic postconditioning in human using surrogate markers of myocardial salvage has yielded conflicting results [41]. Figure 4 illustrates intracellular signaling involved in the cardioprotective response stimulated by postconditioning in cardiac cells.

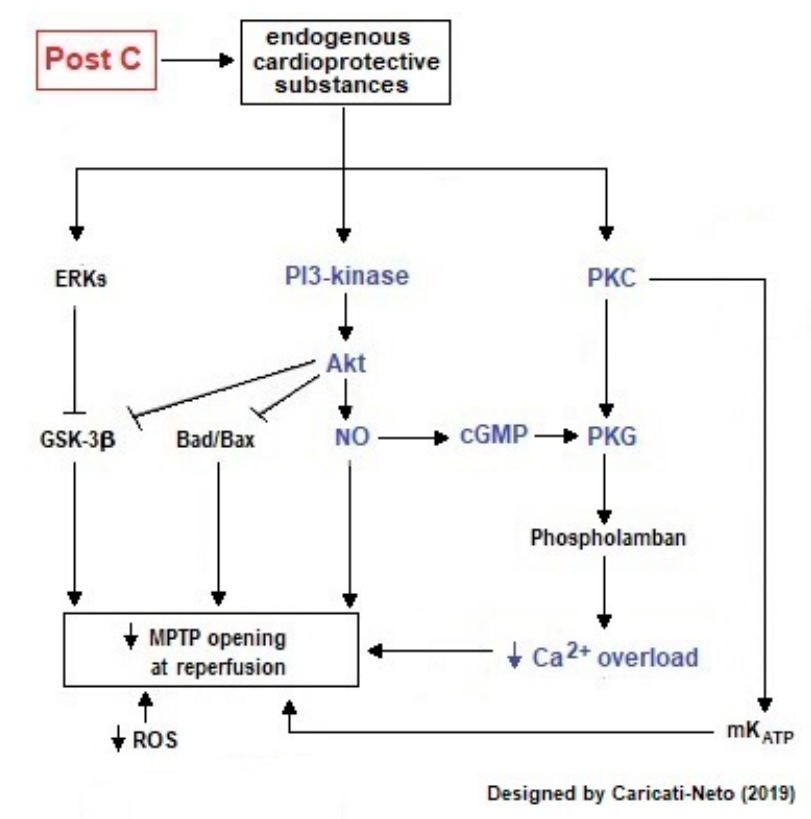

Figure 4. Intracellular signaling involved in cardioprotective response stimulated by ischemic postconditioning (PostC) in cardiac cells. This figure illustrates that PostC activates cellular survival pathways mediated by PI3K/Akt and increases cytosolic levels of NO in cardiac cells. This increase in NO biosynthesis activates intracellular signaling mediated by GC/cGMP/PKG pathway that produces increments in the activity of $\mathrm{mK}_{\mathrm{ATP}}$ channels, preserving the mitochondrial bioenergetics, and preventing the prolonged opening of the MPTP. The arrows represent activation signal and " $\mathrm{T}$ " bars represent inhibition signal. 


\subsubsection{Remote Ischemic Conditioning}

Several studies have shown that a cardioprotective response can also be stimulated by brief cycles of I/R at a remote non-cardiac site [43-48]. This cardioprotective strategy known as remote ischemic conditioning was initially regarded as a laboratory curiosity and somewhat neglected, but gained popularity when it was stimulated from organs remote from the heart, and was later successfully translated to humans [43-48]. Remote conditioning by short repetitive cycles of I/R on an extremity reduces infarct size and improves the prognosis of patients with reperfused myocardial infarction [44,46]. In addition, it also protects the vasculature and various other parenchymal organs from $\mathrm{I} / \mathrm{R}$ injury $[44,46]$. With respect to the time frame, remote ischemic conditioning can be classified as pre- (before the target organ ischemia), per- (during the target organ ischemia) or post- (after the target organ ischemia) conditioning [45-48]. When the time lag between the remote conditioning stimulus and the target ischemia is of longer duration than minutes, there is delayed remote ischemic conditioning [45-48]. The intramyocardial signal transduction of remote conditioning appears to be very similar to that of local conditioning, however, the transfer signal from the remote tissue or organ to the heart or other target organs is still enigmatic $[47,48]$.

Remote ischemic conditioning is obviously a systemic response and the details of the signal transduction involved in this response are largely unclear. However, it has been proposed that signal transduction in remote ischemic conditioning in the myocardium is remarkably similar to that of local ischemic pre-and postconditioning $[47,48]$. Neuronal and humoral mechanisms are involved in the signal transfer from the peripheral stimulus site to the heart $[47,48]$. They act in concert and interact on three different levels: stimulus, systemic and target organ. At the stimulus level, peripheral sensory nerves are directly activated and humoral factors are released that subsequently activate the peripheral sensory nerves $[47,48]$. The importance of these nerves in cardioprotection stimulated by remote ischemic conditioning was evidenced by the loss of this response through the peripheral nerve transection or local anesthesia [48]. At the systemic level, peripheral sensory afferent nerves travel to the spinal cord, project into automonic centers of the central nervous system and this results in stimulation of efferent vagal nerves $[47,48]$. This vagal stimulation releases acetylcholine to activate muscarinic receptors in the target and non-target organs [47,48]. Activation of muscarinic receptors in non-target organs stimulates the release of humoral factors, which subsequently act on the target organs $[47,48]$. In the target organ, the stimulation by humoral factors of intrinsic autonomic nerves and intracardiac ganglia, activates different classes of receptors and intracellular signaling pathways involved in cardioprotection $[47,48]$. In fact, remote ischemic conditioning can be abolished by the blockading of ganglionic nicotinic receptors by hexamethonium [48] The blockading of these receptors inhibits impulse transmission from preganglionic to postganglionic neurons of the sympathetic and parasympathetic autonomic system, reducing the activation of cardiac adrenergic and cholinergic receptors [48]. These receptors are involved in the cardioprotective responses [48].

A variety of remote stimuli elicit target organ protection, including electrical stimuli such as transcutaneous electrical nerve stimulation, pharmacological stimuli such as adenosine and bradykinin, mechanical stimuli such as trauma, and cycles of $\mathrm{I} / \mathrm{R}$ on an extremity or organ. Studies in humans and laboratory animals showed that cardioprotective humoral factors can be detected in systemic circulation after cycles of transcutaneous electrical nerve stimulation, and that trauma by transverse abdominal skin incision reduced myocardial infarct size [48]. In addition, the release of humoral cardioprotective factors in response to remote ischemic conditioning was significantly reduced by the blockade of adenosine receptors produced by intra-arterial caffeine infusion [48]. These findings indicate that remote ischemic conditioning can stimulate the cardioprotective response.

\subsubsection{Hypothermia}

Studies using animal models showed that mild therapeutic hypothermia is a powerful cardioprotective strategy, reducing myocardial infarct size, reducing the no-reflow phenomenon, and improving healing after infarction [48-50]. In these experimental studies, various cooling 
techniques were tested including whole-body hypothermia, synchronized hypothermic coronary venous retro-perfusion, heat exchangers, and regional hypothermia targeting the heart alone [48-50]. However, in humans, the most widely used techniques are surface cooling and cooling by endovascular heat-exchange catheters [48-50]. Clinical studies suggest a lack of benefit of this procedure in patients presenting acute myocardial infarction in most trials [20]. The reduction in temperature necessary to produce cardioprotection is mild $\left(32-34^{\circ} \mathrm{C}\right)$, appears to have no detrimental effects on left ventricular function or regional myocardial blood flow, and may improve microvascular reflow to previously ischemic heart tissue [48-50]. Experimental and clinical studies have shown that for therapeutic hypothermia to be effective it must be initiated as early as possible after the onset of ischemia, and initiated before reperfusion [48-50]. The mechanisms involved in cardioprotective response stimulated by hypothermia have yet to be conclusively determined but may include a decrease in tissue metabolic rate, preservation of high energy phosphates, a reduction in tissue apoptosis or induction of heat shock proteins.

2.1.5. Physiological and Pathological Conditions that Potentially Stimulate the Cardioprotective Response

Several studies have indicated that regular practice of physical exercise constitutes a physiological condition that can potentially stimulate the cardioprotective response [51-53]. It is well established that moderate exercise is an effective and economic way to prevent and treat cardiovascular diseases, because exercise induces cardiac hypertrophy and neo-angiogenesis, essential determinants for cardioprotection [51-53]. Similar to ischemic preconditioning, the practice of moderate (1 to 3 episodes of exercises per week) and high-intensity exercise can decrease infarct size following myocardial infarction [51-53]. It has been proposed that moderate exercise induces the intracellular IGF-1-PI3K-Akt, $\mathrm{NO}, \mathrm{C} / \mathrm{EBP} \beta$, and PGC- $1 \alpha$ signaling pathways, promoting protection against cardiac ischemic disease, cardiac aging and cardiac metabolic derangement [54]. One mechanism involved in this process is the upregulation of eNOS activity and action in vascular endothelium, which contributes to cardioprotection [55]. Patients who practice regular exercise have more red blood cells with functional eNOS, which contributes to systemic nitrite homeostasis and cardioprotection [55]. These findings indicate that the regular practice of physical exercise can potentially stimulate the cardioprotective response.

Some lines of investigation suggest that sympathetic hyperactivity associated to arterial hypertension constitutes a pathological condition that can potentially stimulate the cardioprotective response [42,56-58]. Studies performed in humans and animal models of primary arterial hypertension showed that this cardiovascular disease is associated with increased peripheral vascular resistance, progressive cardiac hypertrophy and heart failure, and sympathetic hyperactivity [56]. Spontaneously hypertensive rats (SHR) represent the main animal model of study of human arterial hypertension [56]. In these animals and humans, the arterial hypertension causes a significant reduction in microvascular density and blood supply in several organs, including the heart [56]. The reduction in the density of myocardial capillaries, and dysfunction in the process of angiogenesis during the development of hypertension leads to moderate ischemia [56]. Other important factor that contributes to this reduction of microvascular density is apoptosis of endothelial cells caused by increased oxidative stress [56]. Some studies have proposed that the moderate ischemia associated to hypertension can stimulate cardioprotective response, mimetizing the ischemic preconditioning [33,34,39,40,42,57,58]. Our studies conducted in SHR have shown a reduced incidence of arrhythmias and lethality when this animal model of hypertension was submitted to cardiac I/R injury, similar to that previously described with the animals treated with ischemic pre- and postconditioning during cardiac $I / R$ injury $[33,42]$. These findings suggest that the sympathetic hyperactivity associated to hypertension can potentially stimulate the cardioprotective response. 


\subsection{Pharmacological Strategies of Cardioprotection}

As mentioned above, cardiac cells possess intracellular signaling pathways that, when stimulated, protect these cells against the damage caused by I/R injury. However, this ability of cardiac cells to protect itself against injury can be stimulated by several classes of pharmacological agents, including catecholamines, purines (adenosine), opioids, endothelin, angiotensin, bradykinin, acetylcholine, testosterone, estrogens, adrenomedullin, phenylephrine, and others $[20,59,60]$. This pharmacological cardioprotection is mainly mediated by activation of cell receptors and intracellular signaling pathways involved in the survival of cardiac cells [20]. On this topic, we analyze the cardioprotective effects stimulated by agonists of $\beta$-adrenoceptors ( $\beta$-AR) or adenosine receptors, L-type VDCC or MCU blockers, modulators of NO biosynthesis or NCX, resveratrol, methylene blue and intestinal lipase inhibitors.

\subsubsection{Cardioprotection Stimulated by Agonists of $\beta-A R$}

In arterial hypertension in humans and in laboratory animals (SHR), an association between the reduction of angiogenesis and the low expression of the VEGF receptor type II (KDR) has been shown $[61,62]$. In addition, the hyperactivity of cervical, splanchnic and renal sympathetic neurons was shown in these models of hypertension, suggesting that this cardiovascular disease is intimately related to sympathetic hyperactivity [63-66]. Our studies using SHR showed that this animal model of arterial hypertension presents reduced incidence of arrhythmias and lethality when submitted to cardiac I/R injury [42]. These findings suggest that the cardioprotective response observed in hypertensive animals can be directly associated to sympathetic hyperactivity [41].

Several studies have shown that non selective and selective agonists of $\beta$-AR stimulate cardioprotection against cardiac I/R injury [67-69]. It was shown that treatment with non selective agonists $\beta$-AR (isoproterenol) and selective agonists of $\beta_{1}$-AR (denopamine), $\beta_{2}$-AR (formoterol and clenbuterol) and $\beta_{3}$-AR (BRL37344) reduced ventricular arrhythmias and infarct size in laboratory animals submitted to cardiac I/R injury [67-69]. A single dose of BRL37344 before reperfusion improved long-term left ventricular function in animals submitted to cardiac $I / R$ injury [69]. Activation of $\beta_{3}$-AR stimulates cellular survival pathways mediated by PI3K/Akt and increases cytosolic levels of NO in cardiac cells [69]. This increase in NO biosynthesis activates intracellular signaling mediated by the GC/cGMP/PKG pathway, which produces an increment in the activity of mKTP channels, preserving the mitochondrial bioenergetics, attenuating excitation-contraction decoupling, and thus reducing the incidence of severe arrhythmias and cellular death (see Figure 2) [67-69]. In addition, activation of $\beta_{1 / 2}$-AR stimulates the increment of intracellular cAMP concentration in cardiac cells, which in turn, increases the cAMP efflux mediated by multidrug resistance protein transporters and elevates the extracellular cAMP concentration and adenosine, thus culminating in activation of adenosine receptors [42]. These cellular responses mediated $\beta$-AR reduce cytosolic $\mathrm{Ca}^{2+}$ overload, oxygen consumption and ATP deficit [67-70].

Our studies have showed that the activation of cardiac $\beta$-AR with isoproterenol stimulates the cardioprotective responses in rats submitted to I/R injury, similar to that observed in hypertensive animals [42]. In addition, our studies have showed that these cardioprotective response stimulated by agonists of $\beta$-AR was totally eliminated by pretreatment of animals with antagonist of $\beta_{1}$-AR (atenolol) [42]. These findings support the direct involvement of $\beta$-AR in the cardioprotective response. Thus, this response can be pharmacologically stimulated by agonists of these receptors.

\subsubsection{Cardioprotection Stimulated by Agonists of Adenosine Receptors}

Adenosine generated by ATP hydrolysis exerts its biological effects through interaction with $\mathrm{P}_{1}$ (adenosine receptors), which are divided into four sub-types of metabotropic receptors, named $A_{1}, A_{2 a}$, $A_{2 b}$ and $A_{3}$ [71]. The $A_{1}$ receptors are involved in the regulation of the heart and renal function and vascular tone (vasoconstriction), while the $A_{2 a}$ and $A_{2 b}$ receptors participate in the cardioprotection 
process [72,73]. It was shown that adenosine induces NO release, increasing the release of cysteinyl leucotrienes and stimulating the cardioprotective response [74]. The NO production is conditioning with protein S-nitrosylation (SNO), another critical component of cardioprotection mediated by NO in ischemic pre- and postconditioning [75]. These finding support the direct involvement of adenosine receptors in cardioprotective response. Thus, this response can be pharmacologically stimulated by agonists of these receptors.

\subsubsection{Cardioprotection Stimulated by Blockers of L-type VDCC}

The VDCC blockers constitute a group of drugs clinically used in the treatment of cardiovascular diseases, which include cardiac arrhythmias, Prinzmetal's angina, and arterial hypertension. These drugs promote vasodilation, reduction of heart rate, reduction of atrioventricular conduction and arrhythmias [76]. There are three classes of L-type VDCC blockers: dihydropyridines, benzothiazepines and phenylalkylamines [76].

Dihydropyridines (nifedipine, amilodipine, felodipine, isradipine, lercanidine, manidipine, nicardipine, nitrendipine, nimodipine and nisoldipine) and benzothiazepines (diltiazem) preferentially act on the VDCC in smooth muscle cells, promoting vasodilation and reduction in peripheral vascular resistance [76]. Phenylalkylamines (verapamil) preferentially act on the VDCC in cardiac tissue and the conduction system, reducing cardiac activity [77]. Nifedipine is clinically used as antihypertensive, vasodilator and tocolytic agent, and is indicated for the treatment of systemic and pulmonary arterial hypertension, and stable angina pectoris [76,77]. In animal models of cardiac I/R injury, administration of nifedipine before ischemia (10-15 $\mathrm{min}$ ) reduces the incidence of ventricular tachyarrhythmias, ventricular fibrillation, and lethality [78-81]. Nicardipine and nimodipine also reduce the incidence of arrhythmias in different models of cardiac I/R injury when given prior to ischemia [80].

Our studies have showed that treatment with nifedipine before ischemia or reperfusion reduces the incidence of ventricular arrhythmias, atrioventricular blockade and lethality in animals submitted to cardiac I/R injury due to attenuation in cytosolic $\mathrm{Ca}^{2+}$ overload in cardiac cells $[81,82]$. When administrated before reperfusion, this cardioprotective effect of nifedipine was lower in comparison to administration before ischemia [81,82]. This result is due to cytosolic $\mathrm{Ca}^{2+}$ overload generated during ischemia and increased depolarization of cardiomyocytes at the onset of reperfusion, which reduces the cardioprotective efficacy of nifedipine [81-85]. Clinical studies suggest that post-ischemia treatment with nifedipine in patients with acute myocardial infarction reduced the incidence of ventricular arrhythmias, but was unable to reduce lethality [86-91]. In vitro studies conducted in isolated rat heart showed that cardiac arrhythmias produced by oxygen deprivation (30 $\mathrm{min}$ ) followed by reoxygenation $(45 \mathrm{~min}$ ) were prevented by the treatment of the heart with L-type VDCC blockers [90]. These findings suggest that L-type VDCC blockers produce cardioprotective effects.

\subsubsection{Cardioprotection Stimulated by Inhibitors of MUC}

Mitochondria are decisive for cellular survival and death. These organelles play a crucial role in the maintenance of ionic gradients and excitation-contraction coupling in cardiac cells because they provide energy, as well as acting as key organelles in the regulation of intracellular levels of $\mathrm{Ca}^{2+}$ [16]. In mammalian cardiac cells, the mitochondrial network occupies $30 \%$ of the cellular volume and accounts for $95 \%$ of cellular ATP production. The $\mathrm{Ca}^{2+}$ influx into mitochondria activates dehydrogenases of Krebs cycle, thus stimulating the production of ATP [92]. In cardiac cells, the MCU is one of the major pathways of $\mathrm{Ca}^{2+}$ influx into mitochondria [92], and the opening of this $\mathrm{Ca}^{2+}$ channel depends on the mitochondrial membrane potential [92]. In physiological conditions, the $\mathrm{Ca}^{2+}$ influx mediated by MCU produces transient increment in $\left[\mathrm{Ca}^{2+}\right] \mathrm{m}$, increasing the activity of dehydrogenases of Krebs cycle, and consequently stimulating the ATP synthesis [16,92,93].

During ischemia, a lack of supply oxygen as an electron acceptor reduces the flow of electrons along the respiratory chain and induces depolarization of the inner mitochondrial membrane, limiting the formation of ATP in cardiac cells $[92,93]$. This ATP deficit dramatically compromises the 
ATP-dependent cellular processes, including transmembrane ion transport, resulting in ionic imbalance and consequently cytosolic $\mathrm{Ca}^{2+}$ overload $[92,93]$. This event collapses the mitochondrial function and ATP production due to $\mathrm{Ca}^{2+}$ overload in matrix mitochondrial mediated by the increment of $\mathrm{Ca}^{2+}$ influx via MCU [92,93]. During reperfusion, the cytosolic and mitochondrial $\mathrm{Ca}^{2+}$ overload is aggravated due to alterations in NCX activity and the increment in the formation of free radicals $[92,93]$. Mitochondrial $\mathrm{Ca}^{2+}$ overload caused by $\mathrm{I} / \mathrm{R}$ interferes in cardiac excitation-contraction coupling, increases the production of free radicals, stimulates the persistent opening of MPTP, and favors the formation of $\mathrm{Ca}^{2+}$ phosphate crystals, compromising the integrity of the internal mitochondrial membrane [92-95]. Thus, attenuation of mitochondrial $\mathrm{Ca}^{2+}$ overload prevents cardiac collapse, improves the recovery of contractile function and confers cardioprotection against injuries caused by I/R [96-100].

It was shown that inhibitors of $\mathrm{MCU}$, such as red ruthenium and Ru360, reduce the $\mathrm{Ca}^{2+}$ influx in cardiac cells producing cardioprotective effects, due mainly to attenuation in mitochondrial $\mathrm{Ca}^{2+}$ overload and preservation of functional integrity of the mitochondria, especially the ATP production $[82,92,99,100]$. Our studies showed that the treatment of animals submitted to cardiac $\mathrm{I} / \mathrm{R}$ injury with inhibitors of MUC, before ischemia or reperfusion, reduced the incidence of arrhythmias and lethality due to attenuation in mitochondrial $\mathrm{Ca}^{2+}$ overload in cardiac cells [82]. However, administration of high doses of red ruthenium can produce cardiotoxic effects, due to inhibition of $\mathrm{Ca}^{2+}$ release from SR, due to interaction of this MUC inhibitor with RyR, tubulin and $\mathrm{Ca}^{2+}$-ATPases [82,101-103]. These findings indicate that the inhibitors of MCU produce cardioprotective effects.

\subsubsection{Cardioprotection Stimulated by Modulators of Plasma Membrane NCX}

Oxygen deprivation caused by cardiac I/R injury leads to a deficit in ATP production in cardiac cells due to inhibition of ATP-dependent ion transporters, such as $\mathrm{Na}^{+} / \mathrm{K}^{+}$ATPase. This inhibition leads to an increase in $\left[\mathrm{Na}^{+}\right] \mathrm{c}$, which acts as driving force to reverse the transport of $\mathrm{Na}^{+}$and $\mathrm{Ca}^{2+}$ by plasma membrane NCX, causing cytosolic $\mathrm{Ca}^{2+}$ overload, which favors an increase in the incidence of arrhythmias during ischemia and early reperfusion [104]. Treatment with modulators of plasma membrane NCX, such as KB-R794 and SEA 0400, increase contractile recovery after ischemia, reducing cytosolic accumulation of $\mathrm{Ca}^{2+}$ and mitochondrial influx of $\mathrm{Na}^{+}$on reperfusion in hearts submitted to cardiac I/R injury [104-106].

Low molecular weight heparins (LMWH), such as trisulfated disaccharide derived from heparin (TDH), have antiarrhythmic and cardioprotective properties [105,107-114]. The oligo-H LMWH, or 2-O-desulfated heparin and 3-O (HDSO) given before ischemia, prevents the onset of ventricular arrhythmias and reduces lethality caused by cardiac I/R injury [106,107]. Our studies have shown that the treatment with $\mathrm{LMWH}$, such as enoxaparin, ardeparin and TDH, prevents the electrically-induced arrhythmias in isolated rat right atrium and heart [113]. Modulation of plasma membrane NCX combined with blocking of $\mathrm{Ca}^{2+}$ and $\mathrm{Na}^{+}$currents by LMWH attenuates the $\mathrm{Na}^{+}$and $\mathrm{Ca}^{2+}$ overload in cardiac cells, reducing the incidence of arrhythmias and lethality caused by cardiac I/R injury [113]. Other mechanisms can be involved in cardioprotective effects of LMWH, including blockade of L-type VDCC and $\mathrm{Na}^{+}$channels $[113,114]$. These results demonstrate that the modulators of plasma membrane NCX produce cardioprotective effects.

\subsubsection{Cardioprotection Stimulated by Modulators of NO Biosynthesis}

In cardiac cells, NO is synthetized by action of NOS isoforms on L-arginine. NO participate in cellular $\mathrm{Ca}^{2+}$ homeostasis and excitation-contraction coupling, producing cardioprotection [115-118]. Administration of L-arginine and NO donors (sodium nitroprusside) and arginase inhibitors (N-hydroxy-nor-L-arginine or NOHA) reduces the incidence of cardiac arrhythmias and myocardial lesions caused by $\mathrm{I} / \mathrm{R}$ injury $[119,120]$. Administration of L-arginine increases plasma concentration of superoxide dismutase, total thiois and ascorbate, and reduces the plasma concentration of xanthine 
oxidase and malondialdehyde $[117,118]$. This cause an increase in the activity of antioxidant enzymes in cardiac cells, attenuating free radical formation stimulated by I/R injury [121].

NO formed from L-arginine regulates different cellular processes by activation of soluble GC, increase in cGMP formation and PKG activation [122]. The PKG attenuates $\mathrm{Na}^{+}$and $\mathrm{Ca}^{2+}$ cytosolic overload during reperfusion by phosphorylating of fosfoleman $\left(\mathrm{Na}^{+} / \mathrm{K}^{+}\right.$ATPase modulating protein), increasing the $\mathrm{Na}^{+}$efflux via $\mathrm{Na}^{+}$pump, and reduce the $\mathrm{Ca}^{2+}$ influx via plasma membrane NCX [122]. This PKG action contributes to the reduction of myocardial contractile dysfunctions and the appearance of arrhythmias caused by cardiac I/R injury [123]. PKG stimulates the opening of mKATP via PKC and inhibits the opening of MTPM, reducing the release of $C$ cytochrome and activation of pro-apoptotic cascades [124]. In the activated state, PKG acts on L-type VDCC, reducing the influx of $\mathrm{Ca}^{2+}$ to cytosol and phosphorylates fosfolambam, increasing the sequestration of cytosolic $\mathrm{Ca}^{2+}$ by SR via SERCA [125]. PKG phosphorylates $\mathrm{TnI}$ reduce the sensitivity of $\mathrm{TnT}$ to $\mathrm{Ca}^{2+}[125]$ and phosphorylates the titin, reducing contractile tone of cardiac cells [126].

Our studies have shown that the administration of micromolar concentrations of L-arginine or sodium nitroprusside reduces the heart rate and contraction force of the isolated heart ventricle in rats submitted to prolonged tissue hypoxia $[81,82,127]$. Our studies also showed that administration of L-arginine produces protective actions against lesions by I/R injury in different organs, such as the liver and intestine [128,129]. These findings demonstrate that the L-arginine produces cardioprotective effects.

Figure 5 illustrates the intracellular signaling involved in cardioprotective response stimulated by drugs that modulate the activity of proteins involved in cellular $\mathrm{Ca}^{2+}$ homeostasis (L-type VDCC, NCX and MCU) and NO biosynthesis in cardiac cells.

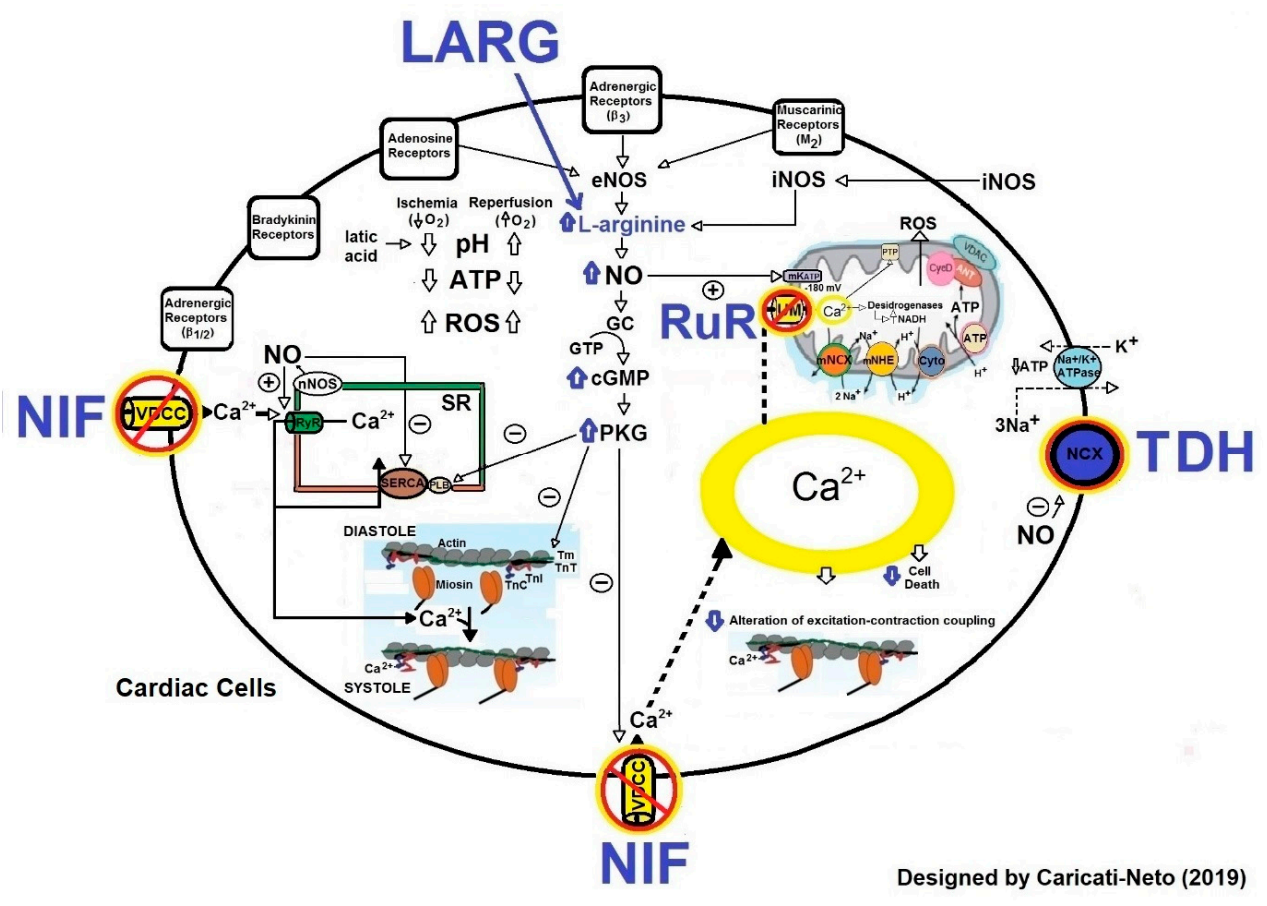

Figure 5. Molecular mechanisms involved in pharmacological cardioprotection. This figure illustrates that the blockade of L-type VDCC by nifedipine (NIF), NCX by TDH, MUC by Ruthenium Red $(\mathrm{RuR})$ and the increase of NO biosynthesis by L-arginine (LARG), produce cardioprotective effects. These effects are resultant of attenuation in cytosolic and mitochondrial $\mathrm{Ca}^{2+}$ overload, reduction in mitochondrial collapse, preservation in ATP production, reduction in ROS production and attenuation in excitation-contraction decoupling. The effects of these drugs attenuate or prevent cardiac arrhythmias and cell death caused by cardiac I/R injury. The continuous and dashed arrows represent activation signal and $\Theta$ symbol represents inhibition signal. 


\subsubsection{Cardioprotection Stimulated by Resveratrol}

Resveratrol (3,5,4'-trihydroxy-trans-stilbene) is a naturally occurring polyphenol antioxidant compound found in Polygonum cuspidatum, grapes, peanuts and berries, as well as their manufactured products, especially red wine, with cardioprotective effects. Resveratrol is a pharmacologically active compound that interacts with multiple targets in a variety of cardiovascular disease models to exert protective effects or induce a reduction in cardiovascular risks [130]. Studies in humans showed that when consumed daily in low concentrations, resveratrol prevents cardiac infarct, improves left ventricular diastolic and endothelial function, reduces the LDL-cholesterol serum levels, and protects against coronary artery disease [131,132].

The cardioprotective effects of resveratrol result from multiple biological actions. This polyphenol exerts protective effects against mitochondrial oxidative stress and apoptosis in neonatal rat cardiac cells induced by hypoxia/reoxygenation injury [133], and increase high-energy compound contents and expression of protein involved in NO pathway in these cells [134,135]. In addition, it decreases catalase synthesis and increases peroxidase and superoxide dismutase activity [136]. Resveratrol reduces the palmitic acid-induced endothelial ROS levels in human aortic endothelial cells. Resveratrol induces endothelial cell autophagy, via AMP-activated protein kinase (AMPK)/mTOR that mediate the effect of resveratrol on ROS reduction [137]. Resveratrol also prevents MPTP opening in myocardial ischemia/reperfusion injury, which was achieved by regulating voltage-dependent anion channel 1 (VDAC1) [138]. The anoxia/reoxygenation injury enhanced VDAC1 phosphorylation, whereas pretreatment with resveratrol dephosphorylated VDAC1 through the Akt-GSK3 $\beta$ pathway, protecting cardiac cells against I/R injury [138]. Other mechanisms are involved in the cardioprotective effects of resveratrol, including the modulation of NHE and attenuation of cytosolic and mitochondrial $\mathrm{Ca}^{2+}$ overload [139]. Resveratrol upregulates adiponectin (APN) multimerization in adipocytes, attenuating I/R injury through APN/AMPK signaling [140]. These findings suggest that resveratrol produces cardioprotective effects.

\subsubsection{Cardioprotection Stimulated by Methylene Blue}

Methylene blue is a redox drug with reported protective effects on mitochondria. The methylene blue ameliorates cyanide toxicity by normalizing the oxidation-reduction state and $\mathrm{Ca}^{2+}$ channels function [141]. Methylene blue does not interfere with NOS, but potently inhibits GC, reducing cGMP synthesis and attenuating vascular smooth muscle relaxation $[142,143]$. The cGMP is an intracellular cardioprotective agent, and its actions account for the low susceptibility to ventricular fibrillation encountered in hearts reperfused after sustained ischemia [143].

Vasoplegia is a term that describes excessive loss of vascular muscle tone leading to a distributive shock status [144]. Vasoplegic syndrome after cardiac surgery is a condition characterized by a hypotension increased cardiac index, low systemic vascular resistance, normal filling pressures, and increased vasopressor and fluid requirements [144]. The use of methylene blue in vasoplegia postcardiac surgery is associated with rapid recovery of hemodynamics, a briefer need for vasopressors, less level mortality, less incidence of renal failure, and shorter length of stay [144].

The methylene blue counteracts the effects of hydrogen sulfide cardiotoxicity by improving cardiac cells contractility and intracellular $\mathrm{Ca}^{2+}$ homeostasis disrupted by hydrogen sulfide poisoning [141]. In vivo, methylene blue restores cardiac contractility depressed by sulfide and protects against arrhythmias [141]. The protective effects are mainly due to attenuation in excitation-contraction coupling defects (cellular $\mathrm{Ca}^{2+}$ homeostasis and L-type VDCC), reduction in the risk of arrhythmias by stabilization of membrane potential, and preservation of cellular bioenergetics [141]. These finding suggest that methylene blue produces cardioprotective effects. 


\subsubsection{Cardioprotection Stimulated by Inhibitors of Intestinal Lipase}

Metabolic syndrome is a complex disorder represented by a set of cardiovascular risk factors usually related to central fat deposition and insulin resistance, and it is highly associated with cardiovascular disease, increasing overall mortality by 1.5 times and cardiovascular mortality by 2.5 times [145-148]. In this syndrome, the patient presents comorbidities, for example, dyslipidemia, a disease characterized by the presence of elevated levels of triglycerides (increase in VLDL and LDL-cholesterol) and decreased levels of HDL-cholesterol. Patients with this disease demonstrate alteration in the density and particle size of the lipoprotein, predominantly the type B pattern (small and dense LDL). This association is responsible for the atherogenic character and the inflammatory nature of dyslipidemia and contributes to the increased risk of cardiovascular diseases when compared to those without dyslipidemia and metabolic syndrome $[149,150]$. The inhibitors of intestinal lipase, such as orlistat, promote body weight reduction, and the consequent weight loss is strongly associated with improvement in blood pressure $[149,150]$. Our studies have showed that treatment with the inhibitor of intestinal lipase orlistat for 10 days reduced the levels of CK in normotensives rats submitted to cardiac I/R injury [151]. These results may be associated to the effect of orlistat on endothelial function and LDL reduction [151]. However, the treatment with orlistat was not able to reverse the increase in serum CK-MB induced by cardiac I/R injury [151]. Our studies also demonstrated that the treatment for 10 days with orlistat decreased ventricular arrhythmias, atrioventricular blocks and lethality in normotensive rats submitted to cardiac I/R injury, indicating that treatment with orlistat could attenuate or prevent myocardial lesions produced by acute myocardial infarction in humans [151]. These finding indicate that the inhibitors of intestinal lipase produce cardioprotective effects.

\section{Conclusions}

Since the discovery that cardiac cells possess intracellular signaling pathways that, when stimulated, protect these cells against the damage caused by I/R injury, several cardioprotective strategies have been proposed for the treatment of IHD, including acute myocardial infarction. This review focused on the recent advances in non-pharmacological and pharmacological strategies to protect the myocardium of lesions caused by $\mathrm{I} / \mathrm{R}$ injury. Several non-pharmacological procedures stimulate the cellular signaling pathways involved in the cardioprotective response. In this review, we focused on the cardioprotection stimulated by ischemic pre- and post-conditioning, remote ischemic conditioning, hypothermia, and some physiological and pathological conditions that potentially stimulate the cardioprotective response such as the regular practice of physical exercise and sympathetic hyperactivity. In addition, different classes of drugs stimulate the cellular signaling pathways involved in cardioprotective response. In this review, we focused on the cardioprotection stimulated by agonists of $\beta$-AR or adenosine receptors, L-type VDCC or MCU blockers, modulators of NO biosynthesis or NCX, resveratrol, methylene blue and intestinal lipase inhibitors. Although the translation of ischemic postconditioning and remote ischemic conditioning protocols to patients with acute myocardial infarction has been fairly successful, the pharmacological recruitment of cardioprotective signaling has been largely disappointing to date due to the complexity involved in this process. It is important to mention that the most of the cardioprotective drugs are effective when administrated before ischemia, and only in experimental assays performed under controlled conditions. Thus, no definitive human cardioprotective strategy exist.

Although a lot of scientific information about the cellular and molecular mechanisms involved in the cardioprotective responses has been acquired, there are two major outstanding issues to be addressed in the future: (1) understanding the spatiotemporal relationship between chemical messengers and receptors involved in intracellular signaling responsible to cardioprotective response, and (2) devising therapeutic strategies against myocardial diseases based on cardioprotective signaling. Future research is necessary for an adequate understanding of the molecular mechanisms involved in cardioprotection and clinical studies are required to properly test the clinical efficacy and safety of potential cardioprotective strategies. 
Author Contributions: This manuscript was written by A.C.-N. in collaboration with P.R.E. and F.S.M.-R.

Funding: This work was supported with financial resources from Fundação de Amparo à Pesquisa do Estado de São Paulo (FAPESP) obtained by ACN (FAPESP \# 2017/25565-1).

Acknowledgments: The authors thank FAPESP and UNIFESP for their financial support. The authors also thank José Gustavo Padrão Tavares and Erisvaldo Amarante de Araújo for their collaboration in experimental assays.

Conflicts of Interest: None of the authors has potential conflicts of interest to be disclosed.

\section{Abbreviations}

\begin{tabular}{|c|c|}
\hline Akt & Protein kinase B \\
\hline AMPK & AMP-activated protein kinase \\
\hline $\mathrm{APN}$ & Adiponectin \\
\hline $\mathrm{AP}$ & Action potential \\
\hline AV & Atrioventricular \\
\hline ATP & Adenosine triphosphate \\
\hline$\beta-A R$ & $\beta$-adrenoceptors \\
\hline $\mathrm{Ca}^{2+}$ & Calcium ion \\
\hline$\left[\mathrm{Ca}^{2+}\right] \mathrm{c}$ & Cytosolic $\mathrm{Ca}^{2+}$ concentration \\
\hline$\left[\mathrm{Ca}^{2+}\right] \mathrm{m}$ & Mitochondrial $\mathrm{Ca}^{2+}$ concentration \\
\hline CICR & $\mathrm{Ca}^{2+}$-induced $\mathrm{Ca}^{2+}$-release \\
\hline CK & Creatine kinase \\
\hline ECG & Electrocardiogram \\
\hline GSK3 $\beta$ & Glycogen synthase kinase $3 \beta$ \\
\hline GC & Guanylate cyclase \\
\hline cGMP & Cyclic guanosine monophosphate \\
\hline HDL & High density lipoproteins \\
\hline HDSO & 2-O-desulfated heparin \\
\hline IHD & Ischemic heart diseases \\
\hline $\mathrm{I} / \mathrm{R}$ & Ischemia and reperfusion \\
\hline LDL & Low density lipoprotein \\
\hline LMWH & Low molecular weight heparins \\
\hline L-NAME & Nw-nitro-L-arginine methyl ester \\
\hline MAPK & Mitogen activated protein kinases \\
\hline $\mathrm{MCU}$ & Mitochondrial $\mathrm{Ca}^{2+}$ uniporter \\
\hline $\mathrm{mK}_{\mathrm{ATP}}$ & Mitochondrial ATP-dependent $\mathrm{K}^{+}$channels \\
\hline $\mathrm{mNHE}$ & Mitochondrial $\mathrm{Na}^{+} / \mathrm{H}^{+}$-exchanger \\
\hline MPTP & Mitochondrial permeability transition pore \\
\hline mTOR & Mammalian target of rapamycin \\
\hline$\left[\mathrm{Na}^{+}\right] \mathrm{c}$ & Cytosolic $\mathrm{Na}^{+}$concentration \\
\hline $\mathrm{NADH}$ & Reduced nicotinamide adenine dinucleotide \\
\hline NCX & $\mathrm{Na}^{+} / \mathrm{Ca}^{2+}$-exchanger \\
\hline NO & Nitric oxide \\
\hline NOHA & N-hydroxy-nor-L-arginine \\
\hline iNOS & Inducible nitric oxide synthase \\
\hline eNOS & Endothelial nitric oxide synthase \\
\hline PI3K & Phosphatidyl inositol 3'-hydroxy kinase \\
\hline PKA & Protein kinase A \\
\hline PKC & Protein kinase $\mathrm{C}$ \\
\hline PKG & Protein kinase $\mathrm{G}$ \\
\hline PMCA & Plasma membrane $\mathrm{Ca}^{2+}$-ATPase \\
\hline ROS & Reactive oxygen species \\
\hline RyR & Ryanodine receptors \\
\hline
\end{tabular}




$\begin{array}{ll}\text { SA } & \text { Sinoatrial } \\ \text { SERCA } & \text { Sarcoendoplasmic reticulum } \\ \text { SHR } & \text { Spontaneously hypertensive rats } \\ \text { SNO } & \text { S-nitrosylation } \\ \text { SR } & \text { Sarcoplasmic reticulum } \\ \text { TnI } & \text { Troponin I } \\ \text { TmT } & \text { Tropomyosin T } \\ \text { TnT } & \text { Troponin T } \\ \text { TDH } & \text { Trisulfated dissacharide derived from heparin } \\ \text { VDAC } & \text { Voltage-dependent anion channel } \\ \text { VDCC } & \text { Voltage-dependent Ca }{ }^{2+} \text { channel } \\ \text { VGEF } & \text { Vascular endothelial growth factor } \\ \text { VLDL } & \text { Very low-density lipoprotein }\end{array}$

\section{References}

1. Moran, A.E.; Forouzanfar, M.H.; Roth, G.A.; Mensah, G.A.; Ezzati, M.; Murray, C.J.; Naghavi, M. Temporal trends in ischemic heart disease mortality in 21 world regions, 1980 to 2010: The Global Burden of Disease 2010 study. Circulation 2014, 129, 1483-1492. [CrossRef] [PubMed]

2. Pasupathy, S.; Tavella, R.; Beltrame, J.F. Myocardial infarction nonobstructive coronary arteries (MINOCA): The past, presente, and future management. Circulation 2017, 135, 1490-1491. [CrossRef] [PubMed]

3. Piccolo, R.; Giustino, G.; Mehran, R.; Windecker, S. Stable coronary artery disease: Revascularisation and invasive strategies. Lancet 2015, 386, 702-713. [CrossRef]

4. Jeong, D.U.; Lim, K.M. The effect of myocardial action potential duration on cardiac pumping efficacy: A computational study. Biomed. Eng. Online 2018, 17, 79. [CrossRef] [PubMed]

5. Bers, D.M. Calcium cycling and signaling in cardiac myocytes. Annu. Rev. Physiol. 2008, 70, 23-49. [CrossRef] [PubMed]

6. Ríos, E. Calcium-induced release of calcium in muscle: 50 years of work and the emerging consensus. J. Gen. Physiol. 2018, 150, 521-537. [CrossRef] [PubMed]

7. Gambardella, J.; Trimarco, B.; Iaccarino, G.; Santulli, G. New insights in cardiac calcium handling and excitation-contraction coupling. Adv. Exp. Med. Biol. 2018, 1067, 373-385.

8. Maltsev, A.V.; Maltsev, V.A.; Stern, M.D. Stabilization of diastolic calcium signal via calcium pump regulation of complex local calcium releases and transiente decay in a computational model of cardiac pacemaker cell with individual release channels. PLoS Comput. Biol. 2017, 13, e1005675. [CrossRef]

9. Kiess, T.O.; Kockskamper, J. SERCA activity controls the systolic calcium increase in the nucleus of cardiac myocytes. Front. Physiol. 2019, 10, 56. [CrossRef]

10. Shattock, M.J.; Ottolia, M.; Bers, D.M.; Blaustein, M.P.; Boguslavskyi, A.; Bossuyti, J.; Bridge, J.H.; Chen-Izu, Y.; Clancy, C.E.; Edwards, A.; et al. $\mathrm{Na}^{+} / \mathrm{Ca}^{2+}$ exchenge and $\mathrm{Na}^{+} / \mathrm{K}^{+}$-ATPase in the heart. J. Physiol. 2015, 593, 1361-1382. [CrossRef]

11. Wei, A.C.; Liu, T.; Winslow, R.L.; O'Rourke, B. Dynamic of matrix-free $\mathrm{Ca}^{2+}$ in cardiac mitochondria: Two componentes of Ca2+ uptake and role of phosphate buffering. J. Gen. Physiol. 2012, 139, 465-478. [CrossRef] [PubMed]

12. Mammuraci, C.; Rafaello, A.; Vecellio Reane, D.; Gherardi, G.; De Mario, A.; Rizzuto, R. Mitochondrial calcium uotake in organ physiology: From molecular mechanism to animal models. Pflugers Arch. 2018, 470, 1165-1179.

13. Luongo, T.S.; Lambert, J.P.; Gross, P.; Nwokedi, M.; Lombardi, A.A.; Shanmughapriya, S.; Carpenter, A.C.; Kolmetzky, D.; Gao, E.; van Berlo, J.H.; et al. The mitochondrial $\mathrm{Na}^{+} / \mathrm{Ca}^{2+}$ exchanger is essential for $\mathrm{Ca}^{2+}$ homeostasis and viability. Nature 2017, 545, 93-97. [CrossRef] [PubMed]

14. Kostic, M.; Sekler, I. Functional properties and model of regulation of the mitochondrial $\mathrm{Na}^{+} / \mathrm{Ca}^{2+}$ exchanger, NCLX. Semin. Cell Dev. Biol. 2019. [CrossRef] [PubMed]

15. Wit, A.L. Afterdepolarizations and triggered activity as a mechanism for clinical arrhythmias. Pacing Clin. Electrophysiol. 2018. [CrossRef]

16. Florea, S.M.; Blatter, L.A. The role of mitochondria for the regulation of cardiac alternans. Front. Physiol. 2010, 1, 141. [CrossRef] 
17. Bliksoen, M.; Baysa, A.; Eide, L.; Bjoras, M.; Suganthan, R.; Vaage, J.; Stenslokken, K.O.; Valen, G. Mitochondrial DNA damage and repair during ischemia-reperfusion injury of the heart. J. Mol. Cell. Cardiol. 2015, 78, 9-22. [CrossRef]

18. Lukas, A.; Botsford, M.W. Cardioprotection induced by ischemic preconditioning in the mammalian heart: Effects on arrhythmogenesis. Can. J. Physiol. Pharmacol. 1997, 75, 316-325. [CrossRef]

19. Ghosh, S.; Standen, N.B.; Galiñanes, M. Evidence for mitochondrial KATP channels as effectors of human myocardial preconditioning. Cardiovasc. Res. 2000, 45, 934-940. [CrossRef]

20. Jovanovic, A. Cardioprotective signaling: Past, present and future. Eur. J. Pharmacol. 2018, 833, $314-319$. [CrossRef]

21. Balakumar, P.; Rohilla, A.; Singh, K.; Singh, M. Modulation of cardioprotective effect of ischemic pre-And postconditioning in the hyperhomocysteinemic rat heart. Methods Find. Exp. Clin. Pharmacol. 2009, 31, 71-79. [CrossRef] [PubMed]

22. Balakumar, P.; Rohilla, A.; Singh, M. Pre-conditioning and postconditioning to limite ischemia-reperfusion induced myocardial injury: What could be the next footstep. Pharmacol. Res. 2008, 57, 403-412. [CrossRef]

23. Matjikava, J.; Kucharska, J.; Pinterova, M.; Pancza, D.; Ravingerova, T. Protection against ischemia-induced ventricular arrhythmias and myocardial dysfunction conferred by preconditioning in the rat heart: Involvement of mitochondrial K (ATP) channels and reactive oxygen species. Physiol. Res. 2009, 58, 9-19.

24. Kolettis, T.M.; Vilaeti, A.D.; Tsalikakis, D.G.; Zoga, A.; Valenti, M.; Tzallas, A.T.; Papalois, A.; Illiodromitis, E.K. Effects of pre-And postconditioning on arrhythmogenesis in the in vivo rat model. J. Cardiovasc. Pharmacol. Ther. 2013, 18, 376-385. [CrossRef] [PubMed]

25. Stokfisk, K.; Ledakowicz-Polak, A.; Zagorski, M.; Zielinska, M. Ischaemic preconditioning-Current knowledge and potential future aplications afyer 30 years of experience. Adv. Med. Sci. 2017, 62, 307-316. [CrossRef]

26. Garlid, K.D.; Halestrap, A.P. The mitochondrial K (ATP) channel-fact or fiction. J. Mol. Cell. Cardiol. 2012, 52, 578-583. [CrossRef] [PubMed]

27. Garlid, A.O.; Jabureck, M.; Jacobs, J.P.; Garlid, K.D. Mitochondrial reactive oxygen species: Which ROS signals cardioprotection? Am. J. Physiol. Heart Circ. Physiol. 2013, 305, H960-H968. [CrossRef]

28. Koretsune, Y.; Marban, E. Mechanism of ischemic contracture in ferret hearts: Relative roles of $\left[\mathrm{Ca}^{2+}\right]_{\mathrm{i}}$ elevation and ATP depletion. Am. J. Physiol. 1990, 258, H9-C16. [CrossRef]

29. Wang, L.; Cherednichenko, G.; Hernandez, L.; Halow, J.; Camacho, S.A.; Figueiredo, V.; Schaefer, S. Preconditioning limits mitochondrial $\mathrm{Ca}^{2+}$ during ischemia in rat hearts: Role of K(ATP) channels. Am. J. Physiol. 2001, 280, H2321-H2328. [CrossRef]

30. Korge, P.; Honda, H.M.; Weiss, J.N. Protection of cardiac mitochondria by diazoxide and protein kinase C: Implications for ischemic preconditioning. Proc. Natl. Acad. Sci. USA 2002, 99, 3312-3317. [CrossRef]

31. Giorgio, V.; Guo, L.; Bassot, C.; Petronilli, V.; Bernardi, P. Calcium and regulation of the mitochondrial permeability transition. Cell Calcium 2018, 70, 56-63. [CrossRef] [PubMed]

32. Baxter, G.F.; Ferdinandy, P. Delayed preconditioning of myocardium: Current perspectives. Basic Res. Cardiol. 2001, 96, 329-344. [CrossRef] [PubMed]

33. Tavares, J.G.P.; Errante, P.R.; Govato, T.C.P.; Vasques, E.R.; Ferraz, R.R.N.; Taha, M.O.; Menezes-Rodrigues, F.S.; Caricati-Neto, A. Cardioprotective effect of preconditioning is more efficient than postconditioning in rats submitted to cardiac ischemia and reperfusion. Acta Cir. Bras. 2018, 33, 588-596. [CrossRef] [PubMed]

34. Vinten-Johansen, J.; Zhao, Z.Q.; Zatta, A.J.; Kin, H.; Halkos, M.E.; Kerendi, F. Postconditioning-A new link in nature's armor against myocardial ischemia-reperfusion injury. Basic Res. Cardiol. 2005, 100, 295-310. [CrossRef] [PubMed]

35. Zhao, Z.Q.; Corvera, J.S.; Halkos, M.E.; Kerendi, F.; Wang, N.P.; Guyton, R.A.; Vinten-Johansen, J. Inhibition of myocardial injury by ischemic post conditioning during reperfusion: Comparison with ischemic preconditioning. Am. J. Physiol. Heart Circ. Physiol. 2003, 285, H579-H588. [CrossRef] [PubMed]

36. Halkos, M.E.; Kerendi, F.; Corvera, J.S.; Wang, N.P.; Kin, H.; Payne, C.S.; Guyton, R.A.; Vinten-Johansen, J.; Zhao, Z.Q. Myocardial protection with postconditioning is not enhanced by ischemic preconditioning. Ann. Thorac. Surg. 2004, 78, 961-969. [CrossRef] [PubMed]

37. Iliodromitis, E.K.; Georgiadis, M.; Cohen, M.V.; Downey, J.M.; Bofilis, E.; Kremastinos, D.T. Protection from post-conditioning depends on the number of short ischemic insults in anesthetized pigs. Basic Res. Cardiol. 2006, 101, 502-507. [CrossRef] 
38. Penna, C.; Mancardi, D.; Raimondo, S.; Geuna, S.; Pagliaro, P. The paradigm of postconditioning to protect the heart. J. Cell. Mol. Med. 2008, 12, 435-458. [CrossRef]

39. Laskey, W.K. Brief repetitive balloon occlusions enhance reperfusion during percutaneous coronary intervention for acute myocardial infarction: A pilot study. Catheter. Cardiovasc. Interv. 2005, 65, 361-367. [CrossRef]

40. Staat, P.; Rioufol, G.; Piot, C.; Cottin, Y.; Cung, T.T.; L'Huillier, I.; Aupetit, J.F.; Bonnefoy, E.; Finet, G.; Andre-Fouet, X.; et al. Postconditioning the human heart. Circulation 2005, 112, 2143-2188. [CrossRef]

41. Giustino, G.; Dangas, G.D. Ischemia-reperfusion injury and ischemic post-conditioning in acute myocardial infarction: Lost in transition. Catheter. Cardiovasc. Interv. 2017, 90, 1068-1069. [CrossRef] [PubMed]

42. Menezes-Rodrigues, F.S.; Errante, P.R.; Tavares, J.G.P.; Ferraz, R.R.N.; Gomes, J.G.; Taha, M.O.; Scorza, C.A.; Scorza, F.A.; Caricati-Neto, A. Pharmacological modulation of $\beta$-adrenoceptors as a new strategy for therapy of myocardial dysfunction induced by ischemia and reperfusion. Acta Cir. Bras. 2019, 34. [CrossRef]

43. Gho, B.C.; Schoemaker, R.G.; van den Doel, M.A.; Duncker, D.J.; Verdouw, P.D. Myocardial protection by brief ischemia in non-cardiac tissue. Circulation 1996, 94, 2193-2200. [CrossRef] [PubMed]

44. Davies, W.R.; Brown, A.J.; Watson, W.; McCormick, L.M.; West, N.E.; Dutka, D.P.; Hoole, S.P. Remote ischemic preconditioning improves outcome at 6 years after elective percutaneous coronary intervention: The CRISP stent trial long-term follow-up. Circ. Cardiovasc. Interv. 2013, 6, 246-251. [CrossRef]

45. Thielmann, M.; Kottenberg, E.; Kleinbongard, P.; Wendt, D.; Gedik, N.; Pasa, S.; Price, V.; Tsagakis, K.; Neuhäuser, M.; Peters, J.; et al. Cardioprotective and prognostic effects of remote ischaemic preconditioning in patients undergoing coronary artery bypass surgery: A single-centre randomised, double-blind, controlled trial. Lancet 2013, 382, 597-604. [CrossRef]

46. Sloth, A.D.; Schmidt, M.R.; Munk, K.; Kharbanda, R.K.; Redington, A.N.; Schmidt, M.; Pedersen, L.; Sørensen, H.T.; Bøtker, H.E. CONDI Investigators. Improved long-term clinical outcomes in patients with ST-elevation myocardial infarction undergoing remote ischaemic conditioning as an adjunct to primary percutaneous coronary intervention. Eur. Heart J. 2014, 35, 168-175. [CrossRef]

47. Heusch, G.; Bøtker, H.E.; Przyklenk, K.; Redington, A.; Yellon, D. Remote Ischemic Conditioning. J. Am. Coll. Cardiol. 2015, 65, 177-195. [CrossRef]

48. Kleinbongard, P.; Skyschally, A.; Heusch, G. Cardioprotection by remote ischemic conditioning and its signal transduction. Pflügers Arch.-Eur. J. Physiol. 2017, 469, 159-181. [CrossRef] [PubMed]

49. Kohlhauer, M.; Berdeaux, A.; Galeh, B.; Tissier, R. Therapeutic hypothermia to protect the heart against acute myocardial infarction. Arch. Cardiol. Dis. 2016, 109, 716-722. [CrossRef]

50. Schwartz, B.C.; Kloner, R.A.; Thomas, J.L.; Bui, Q.; Mayeda, G.S.; Burstein, S.; Hale, S.L.; Economides, C.; French, W.J. Therapeutic hypothermia for acute myocardial infarction and cardiac arrest. Am. J. Cardiol. 2012, 110, 461-466. [CrossRef]

51. Marongiu, E.; Crisafulli, A. Cardioprotection acquired through exercise: The role of ischemic preconditioning. Curr. Cardiol. Rev. 2014, 10, 336-348. [CrossRef] [PubMed]

52. Thijssen, D.H.J.; Redington, A.; George, K.P.; Hopman, M.T.E.; Jones, H. Association of exercise preconditioning with immediate cardioprotection: A review. JAMA Cardiol. 2018, 3, 169-176. [CrossRef] [PubMed]

53. Chowdhury, M.A.; Sholl, H.K.; Sharrett, M.S.; Haller, S.T.; Cooper, C.C.; Gupta, R.; Liu, L.C. Exercise and cardioprotection: A natural defense against lethal myocardial ischemia-reperfusion injury and potential guide to cardiovascular prophylaxis. J. Cardiovasc. Pharmacol. Ther. 2019, 24, 18-30. [CrossRef] [PubMed]

54. Bei, Y.; Zhou, Q.; Sun, Q.; Xiao, J. Exercise as a platform for pharmacotherapy development in cardiac diseases. Curr. Pharm. Des. 2015, 21, 4409-4416. [CrossRef] [PubMed]

55. Suvorava, T.; Cortese-Krott, M.M. Exercise-induced cardioprotection via eNOS; a putative role of red blood cell signaling. Curr. Med. Chem. 2018, 25, 4457-4474. [CrossRef] [PubMed]

56. Feihl, F.; Liaudet, L.; Waeber, B.; Levy, B.I. Hypertension: A disease of the microcirculation? Hypertension 2006, 48, 1012-1017. [CrossRef]

57. Murry, C.E.; Richard, V.J.; Reimer, K.A.; Jennings, R.B. Ischemic preconditioning slows energy metabolism and delays ultrastructural damage during a sustained ischemic episode. Circ. Res. 1990, 66, 913-931. [CrossRef] [PubMed]

58. Hagar, J.M.; Hale, S.L.; Kloner, R.A. Effect of preconditioning ischemia on reperfusion arrhythmias after coronary artery occlusion and reperfusion in the rat. Circ. Res. 1991, 68, 61-68. [CrossRef] 
59. Vynohradova, S.V. The role of angiotensin-converting enzyme gene I/D polymorphism in development of metabolic disorders in patients with cardiovascular pathology. Tsitol. Genet. 2005, 39, 63-70.

60. Alquwaizani, M.; Buckley, L.; Adams, C.; Fanikos, J. Anticoagulants: A Review of the Pharmacology, Dosing, and Complications. Curr. Emerg. Hosp. Med. Rep. 2013, 1, 83-97. [CrossRef]

61. Belgore, F.M.; Blann, A.D.; Li-Saw-Hee, F.L.; Beevers, D.G.; Lip, G.Y. Plasma levels of vascular endothelial growth factor and its soluble receptor (SFlt-1) in essential hypertension. Am. J. Cardiol. 2001, 87, 805-807. [CrossRef]

62. Wang, Z.; Niu, Q.; Peng, X.; Li, M.; Liu, K.; Liu, Y.; Liu, J.; Jin, F.; Li, X.; Wei, Y. Candesartan cilexetil attenuated cardiac remodeling by improving expression and function of mitofusin 2 in SHR. Int. J. Cardiol. 2016, 214, 348-357. [CrossRef] [PubMed]

63. Okamoto, K.; Nosaka, S.; Yamori, Y.; Matsumoto, M. Participation of neural factor in the pathogenesis of hypertension in the spontaneously hypertensive rat. Jpn. Heart J. 1967, 8, 168-180. [CrossRef] [PubMed]

64. Judy, W.V.; Farrel, S.K. Arterial baroreceptor reflex control of sympathetic nerve activity in the spontaneously hypertensive rat. Hypertension 1979, 1, 605-614. [CrossRef] [PubMed]

65. Judy, W.V.; Watanabe, A.M.; Murphy, W.R.; Aprison, B.S.; Yu, P.L. Sympathetic nerve activity and blood pressure in normotensive backcross rats genetically related to the spontaneously hypertensive rat. Hypertension 1979, 1, 598-604. [CrossRef] [PubMed]

66. Ohlstein, E.H.; Kruse, L.I.; Ezekiel, M.; Sherman, S.S.; Erickson, R.; DeWolf, W.E.; Jr-Berkowitz, B.A. Cardiovascular effects of a new potent dopamine beta-hydroxylase inhibitor in spontaneously hypertensive rats. J. Pharmacol. Exp. Ther. 1987, 241, 554-559.

67. Zhang, Q.; Xiang, J.; Wang, X.; Liu, H.; Hu, B.; Feng, M.; Fu, Q. Beta (2)-adrenoceptor agonist clenbuterol reduces infarct size and myocardial apoptosis after myocardial ischaemia/reperfusion in anaesthetized rats. Br. J. Pharmacol. 2010, 160, 1561-1572. [CrossRef]

68. Salie, R.; Moolman, J.A.; Lochner, A. The role of $\beta$-adrenergic receptors in the cardioprotective effects of beta-preconditioning ( $\beta$ PC). Cardiovasc. Drugs Ther. 2011, 25, 31-46. [CrossRef]

69. García-Prieto, J.; García-Ruiz, J.M.; Sanz-Rosa, D.; Pun, A.; García-Alvarez, A.; Davidson, S.M.; Fernández-Friera, L.; Nuno-Ayala, M.; Fernández-Jiménez, R.; Bernal, J.A.; et al. $\beta 3$ adrenergic receptor selective stimulation during ischemia/reperfusion improves cardiac function in translational models through inhibition of mPTP opening in cardiomyocytes. Basic Res. Cardiol. 2014, 109, 422. [CrossRef]

70. Menezes-Rodrigues, F.S.; Tavares, J.G.P.; Errante, P.R.; Vasques, E.R.; Reis, M.C.M.; Luna-Filho, B.; Scorza, F.A.; Caricati-Neto, A.; Bergantin, L.B. Role of the Ca /cyclic AMP-Adenosine signaling pathways in cardioprotection. J. Thromb. Circ. 2017, 3, 1. [CrossRef]

71. Peleli, M.; Fredholm, B.B.; Sobrevia, L.; Carlstrom, M. Pharmacological targeting of adenosine receptor signaling. Mol. Aspects Med. 2017, 55, 4-8. [CrossRef]

72. Zhan, E.; McIntosh, V.J.; Lasley, R.D. Adenosine $\mathrm{A}_{2} \mathrm{~A}$ and $\mathrm{A}_{2} \mathrm{~B}$ receptors are both required for adenosine $\mathrm{A}_{1}$ receptor-mediated cardioprotection. Am. J. Physiol. Heart Circ. Physiol. 2011, 301, H1183-H1189. [CrossRef]

73. Dejerada, Z.; Feliu, C.; Richard, V.; Millart, H. Current knowledge on the role of $\mathrm{P}_{2} \mathrm{Y}$ receptors in cardioprotection against ischemia-reperfusion. Pharmacol. Res. 2017, 118, 5-18. [CrossRef]

74. Singh, L.; Virdi, J.K.; Maslow, L.N.; Singh, N.; Jaggi, A.S. Investigating the possible mechanisms involved in adenosine preconditioning-induced cardioprotection in rats. Cardiovasc. Ther. 2018, 36, e12328. [CrossRef]

75. Shao, Q.; Casin, K.M.; Mackowski, N.; Murphy, E.; Steenberg, C.; Kohr, M.J. Adenosine A1 receptor activation increases myocardial protein-S nitrosothiols and elicits protection from ischemia-reperfusion injury in male and female hearts. PLoS ONE 2017, 12, e0177315. [CrossRef]

76. Elliot, W.J.; Ram, C.V. Calcium channel blockers. J. Clin. Hypertens. 2011, 13, 687-689. [CrossRef]

77. Wang, A.L.; Iadecola, C.; Wang, G. New generations of dihydropyridines for treatment of hypertension. J. Geriatr. Cardiol. 2017, 14, 67-72.

78. Walker, M.J.; Curtis, M.J.; Hearse, D.J.; Campbell, R.W.; Janse, M.J.; Yellon, D.M.; Cobbe, S.M.; Coker, S.J.; Harness, J.B.; Riemersma, R.A.; et al. The Lambeth Conventions: Guidelines for the study of arrhythmias in ischaemia infarction, and reperfusion. Cardiovasc. Res. 1988, 22, 447-455. [CrossRef]

79. Mitrega, K.A.; Varghese, B.; Porc, M.; Krzeminski, T.F. Anti-arrhythmic and hemodynamic effects of oxy nifedipine, oxy nimodipine, oxy nitrendipine and oxy nisoldipine. Pharmacol. Res. 2012, 66, 300-308. [CrossRef] 
80. Apostolakos, M.J.; Varon, M.E. Antiarrhythmic and anti-ischemic properties of calcium-channel antagonists. New Horiz. 1996, 4, 45-57.

81. Tavares, J.G.P.; Menezes-Rodrigues, F.S.; Vasques, E.R.; Reis, M.C.M.; de Paula, L.; Luna-Filho, B.; Errante, P.R.; Caricati-Neto, A.; Bergantin, L.B. A simple and efficient methodology for the study of cardioprotective drugs in animal model of cardiac ischemia-reperfusion. J. Mol. Imaging Dyn. 2017, 7, 1. [CrossRef]

82. Tavares, J.G.P.; Vasques, E.R.; Menezes-Rodrigues, F.S.; Jurkiewicz, A.; Caricati-Neto, A. Cardioprotector effect of nifedipine and ruthenium red against cardiac ischemia and reperfusion injury in rats. J. Pharm. Pharmacogn. Res. 2014, 2 (Suppl. 1), S337.

83. Murphy, C.E.; Wechsler, A.S. Calcium channel blockers and cardiac surgery. J. Card. Surg. 1987, 2, $299-325$. [CrossRef]

84. Nayler, W.G. The calcium antagonist drugs. Med. J. Aust. 1988, 149, 682-686.

85. Opie, L.H. Myocardial stunning are calcium antagonists useful? Cardiovasc. Drugs Ther. 1994, 8 (Suppl. 3), 533-541. [CrossRef]

86. Wang, Q.D.; Pernow, J.; Sjoquist, P.O.; Ryden, L. Pharmacological possibilities for protection against myocardial reperfusion injury. Cardiovasc. Res. 2002, 55, 25-37. [CrossRef]

87. Goldbourt, U.; Behar, S.; Reicher-Reiss, H.; Zion, M.; Mandelzweig, L.; Kaplinsky, E. Early administration of nifedipine in suspected acute myocardial infarction. The Secondary Prevention Reinfarction Israel Nifedipine Trial 2 Study. Arch. Intern. Med. 1993, 153, 345-353. [CrossRef]

88. Tijssen, J.G.P.; Hugenholtz, P.G. Critical appraisal of recent studies on nifedipine and other calcium channel blockers in coronary artery disease and hypertension. Eur. Heart J. 1996, 17, 1152-1157. [CrossRef]

89. Gutstein, D.E.; Fuster, V. Pathophysiologic bases for adjunctive therapies in the treatment and secondary prevention of acute myocardial infarction. Clin. Cardiol. 1998, 21, 161-168. [CrossRef]

90. Avezum, A.; Cavalcanti, A.B.; Souza, A.G.; Farsky, P.S.; Knobel, M. Adjuvant therapy in acute myocardial infarction: Evidence based recommendations. Rev. Assoc. Med. Bras. 1992, 46, 363-368. [CrossRef]

91. Dagenais, F.; Cartier, R.; Holmann, C.; Buluran, J. Calcium-channel blockers preserve coronary endothelial reactivity after ischemia-reperfusion. Ann. Thorac. Surg. 1997, 63, 1050-1056. [CrossRef]

92. Brown, D.A.; O’Rourke, B. Cardiac mitochondria and arrhythmias. Cardiovasc. Res. 2010, 88, $241-249$. [CrossRef]

93. Griffiths, E.J.; Balaska, D.; Cheng, W.H. The ups and downs of mitochondrial calcium signalling in the heart. Biochim. Biophys. Acta 2010, 1797, 856-864. [CrossRef]

94. Duchen, M.R.; Szabadkai, G. Roles of mitochondria in human disease. Essays Biochem. 2010, 47, $115-137$. [CrossRef]

95. Patron, M.; Raffaello, A.; Granatiero, V.; Tosatto, A.; Merli, G.; De Stefani, D.; Wright, L.; Pallafacchina, G.; Terrin, A.; Mammucari, C.; et al. The mitochondrial calcium uniporter (MCU); molecular identity and physiological roles. J. Biol. Chem. 2013, 288, 10750-10758. [CrossRef]

96. Granatiero, V.; De Stefani, D.; Rizzuto, R. Mitochondrial calcium handling in physiology and disease. Adv. Exp. Med. Biol. 2017, 982, 25-47.

97. Miyamae, M.; Camacho, S.A.; Weiner, M.W.; Figueredo, V.M. Attenuation of postischemic reperfusion injury is related to prevention of [Ca2+]m overload in rat hearts. Am. J. Physiol. 1996, 271 Pt 2, H2145-H2153. [CrossRef]

98. Cao, C.M.; Yan, W.Y.; Liu, J.; Kam, K.W.; Zhan, S.Z.; Sham, J.S.; Wong, T.M. Attenuation of mitochondrial, but not cytosolic, $\mathrm{Ca}^{2+}$ overload reduces myocardial injury induced by ischemia and reperfusion. Acta Pharmacol. Sin. 2006, 27, 911-918. [CrossRef]

99. Di Lisa, F.; Schulz, R.; Murphy, E. Preface to mitochondria and cardioprotection. Biochim. Biophys. Acta 2011, 1813, 1261-1262. [CrossRef]

100. García-Rivas, G.J.; Carvajal, K.; Correa, F.; Zazueta, C. Ru360, a specific mitochondrial calcium uptake inhibitor, improves cardiac post-ischaemic functional recovery in rats in vivo. Br. J. Pharmacol. 2006, 149, 829-837. [CrossRef]

101. Zucchi, R.; Ronca-Testoni, S. The sarcoplasmic reticulum $\mathrm{Ca}^{2+}$ channel/ryanodine receptor: Modulation by endogenous effectors, drugs and disease states. Pharmacol. Rev. 1997, 49, 1-51.

102. Hajnóczky, G.; Csordás, G.; Das, S.; Garcia-Perez, C.; Saotome, M.; Sinha Roy, S.; Yi, M. Mitochondrial calcium signalling and cell death: Approaches for assessing the role of mitochondrial $\mathrm{Ca}^{2+}$ uptake in apoptosis. Cell Calcium 2006, 40, 553-560. [CrossRef] 
103. Halestrap, A.P.; Clarke, S.J.; Khaliulin, I. The role of mitochondria in protection of the heart by preconditioning. Biochim. Biophys. Acta 2007, 1767, 1007-1031. [CrossRef]

104. Motegi, K.; Tanonaka, K.; Takenaga, Y.; Takagi, N.; Takeo, S. Preservation of mitochondrial function may contribute to cardioprotective effects of $\mathrm{Na}^{+} / \mathrm{Ca}^{2+}$ exchanger inhibitors in ischaemic/reperfused rat hearts. Br. J. Pharmacol. 2007, 151,963-978. [CrossRef]

105. Antoons, G.; Sipido, K.R. Targeting calcium handling in arrhythmias. Europace 2008, 10, 1364-1369. [CrossRef]

106. Barry, W.H.; Zhang, X.Q.; Halkos, M.E.; Vinten-Johansen, J.; Saegusa, N.; Spitzer, K.W.; Matsuoka, N.; Sheets, M.; Rao, N.V.; Kennedy, T.P. Nonanticoagulant heparin reduces myocyte $\mathrm{Na}^{+}$and $\mathrm{Ca}^{2+}$ loading during simulated ischemia and decreases reperfusion injury. Am. J. Physiol. Heart Circ. Physiol. 2010, 298, H102-H111. [CrossRef]

107. Guarini, S.; Martini, M.C.; Bertolini, A. Reperfusion-Induced Arrhythmias and Lethality Are Reduced by a 2kDa Heparin Fragment. Life Sci. 1995, 57, 967-972. [CrossRef]

108. Mehta, S.R.; Boden, W.E.; Eikelboom, J.W.; Flather, M.; Steg, P.G.; Avezum, A.; Afzal, R.; Piegas, L.S.; Faxon, D.P.; Widimsky, P.; et al. Antithrombotic therapy with fondaparinux in relation to interventional management strategy in patients with Stand non-ST-segment elevation acute coronary syndromes: An individual patient-level combined analysis of the Fifth and Sixth Organization to Assess Strategies in Ischemic Syndromes (OASIS 5 and 6) randomized trials. Circulation 2008, 118, 2038-2046.

109. Montalescot, G.; Zeymer, U.; Silvain, J.; Boulanger, B.; Cohen, M.; Goldstein, P.; Ecollan, P.; Combes, X.; Huber, K.; ATOLL Investigators; et al. Intravenous enoxaparin or unfractionated heparin in primary percutaneous coronary intervention for ST-elevation myocardial infarction: The international randomised open-label ATOLL trial. Lancet 2011, 378, 693-703. [CrossRef]

110. Kohajda, Z.; Farkas-Morvay, N.; Jost, N.; Nagy, N.; Geramipour, A.; Horváth, A.; Varga, R.S.; Hornyik, T.; Corici, C.; Acsai, K.; et al. The effect of a novel highly selective inhibitor of the sodium/calcium exchanger (NCX) on cardiac arrhythmias in in vitro and in vivo experiments. PLoS ONE 2016, 11, e0166041. [CrossRef]

111. Bourgonje, V.J.; Vos, M.A.; Ozdemir, S.; Doisne, N.; Acsai, K.; Varro, A.; Sztojkov-Ivanov, A.; Zupko, I.; Rauch, E.; Kattner, L.; et al. Combined $\mathrm{Na}(+) / \mathrm{Ca}(2+)$ enchanger and L-type calcium channel block as a potential strategy to suppres arrhytmias and mantain ventricular function. Circ. Arrhythmia Electrophysiol. 2013, 6, 371-379. [CrossRef]

112. Demirtas, S.; Karahan, O.; Yazici, S.; Guclu, O.; Caliskan, A.; Tezcan, O.; Kaplan, I.; Yavuz, C. Investigation of possible prophylactic, renoprotective, and cardioprotective effects of thromboprophylactic drugs against ischemia-reperfusion injury. Kaohsiung J. Med. Sci. 2015, 31, 115-122. [CrossRef]

113. de Godoy, C.M.G.; Vasques, E.R.; Caricati-Neto, A.; Tavares, J.G.P.; Alves, J.B.; Duarte, J.; Miranda-Ferreira, R.; Lima, M.A.; Nader, H.B.; Tersariol, I.L.D. Heparin oligosaccharides have antiarrhythmic effect by accelerating the sodium-calcium exchanger. Front. Cardiovasc. Med. 2018, 5, 67. [CrossRef]

114. Knaus, H.G.; Moshammer, T.; Friedrich, K.; Kang, H.C.; Haugland, R.P.; Glossman, H. In vivo labeling of L-type $\mathrm{Ca}^{2+}$ channels by fluorescent dihydropyridines: Evidence for a functional, extracellular heparin-binding site. Proc. Natl. Acad. Sci. USA 1992, 89, 3586-3590. [CrossRef]

115. Andelová, E.; Barteková, M.; Pancza, D.; Styk, J.; Ravingerová, T. The role of NO in ischemia/reperfusion injury in isolated rat heart. Gen. Physiol. Biophys. 2005, 24, 411-426.

116. Ferreira, R. The reduction of infarct size-forty years of research. Rev. Port. Cardiol. 2010, 29, 1037-1053.

117. Ingram, T.E.; Fraser, A.G.; Bleasdale, R.A.; Ellins, E.A.; Margulescu, A.D.; Halcox, J.P.; James, P.E. Low-dose sodium nitrite attenuates myocardial ischemia and vascular ischemia-reperfusion injury in human models. J. Am. Coll. Cardiol. 2013, 61, 2534-2541. [CrossRef]

118. Sobierajski, J.; Kelm, M.; Rassaf, T. New strategies in cardioprotection during acute myocardial infarction: Impact of hypoxic nitrate-nitrite-NO signaling. Dtsch. Med. Wochenschr. 2013, 138, 799-804.

119. Kumar, K.; Nguyen, K.; Waxman, S.; Nearing, B.D.; Wellenius, G.A.; Zhao, S.X.; Verrier, R.L. Potent antifibrillatory effects of intrapericardial nitroglycerin in the ischemic porcine heart. J. Am. Coll. Cardiol. 2003, 41, 1831-1837. [CrossRef]

120. Gonon, A.T.; Jung, C.; Katz, A.; Westerlblad, H.; Shemyakin, A.; Sjoquist, P.O.; Lundberg, J.O.; Pernow, J. Local arginase inhibition during early reperfusion mediates cardioprotection via increased nitric oxide production. PLoS ONE 2012, 7, e42038. [CrossRef]

121. Tripathi, P.; Misra, M.K. Therapeutic role of L-arginine on free radical scavenging system in ischemic heart diseases. Indian J. Biochem. Biophys. 2009, 46, 498-502. 
122. Burley, D.S.; Ferdinandy, P.; Baxter, G.F. Cyclic GMP and protein kinase-G in myocardial ischemia-reperfusion: Opportunities and obstacles for survival signaling. Br. J. Pharmacol. 2007, 152, 855-869. [CrossRef]

123. Madhani, M.; Hall, A.R.; Cuello, F.; Charles, R.L.; Burgoyne, J.R.; Fuller, W.; Hobbs, A.J.; Shattock, M.J.; Eaton, P. Phospholemman Ser69 phosphorylation contributes to sildenafil-induced cardioprotection against reperfusion injury. Am. J. Physiol. Heart Circ. Physiol. 2010, 299, H827-H836. [CrossRef]

124. Costa, A.D.; Garlid, K.D.; West, I.C.; Lincoln, T.M.; Downey, J.M.; Cohen, M.V.; Critz, S.D. Protein kinase G transmits the cardioprotective signal from cytosol to mitochondria. Circ. Res. 2005, 97, 329-336. [CrossRef]

125. Takimoto, E. Cyclic GMP-dependent signaling in cardiac myocytes. Circ. J. 2012, 76, 1819-1825. [CrossRef]

126. Francis, S.H.; Bush, J.L.; Corbin, J.D.; Sibley, D. cGMP-dependent protein kinases and cGMP phosphodiesterases in nitric oxide and cGMP action. Pharmacol. Rev. 2010, 62, 525-563. [CrossRef]

127. Tavares, J.G.P.; Caricati-Neto, A.; Cukierman, S.; Godoy, C.M.G. Electrical stimulation for cardiodepression reverting in closed-loop Langendorff preparation. In Abstract Book of $V$ Latin American Congress on Biomedical Engineering (CLAIB), Sustainable Technologies for the Health of All; Folgueras Méndez, J., Aznielle Rodríguez, T.Y., Calderón Marín, C.F., Llanusa Ruiz, S.B., Castro Medina, J., Vega Vázquez, H., Carballo Barreda, M., Rodríguez Rojas, R., Eds.; Springer: Berlin/Heidelberg, Germany, 2011; p. 33.

128. Taha, M.O.; Simões, M.J.; Haddad, M.A.; Capelato, R.C.; Budny, N.; Matsumoto, A.H.; Soares, P.C.; Santos, W.M.; Armeato, G.D.; Araki, C.M.; et al. L-arginine supplementation protects against hepatic ischemia-reperfusion lesions in rabbits. Transpl. Proc. 2009, 41, 816-819. [CrossRef]

129. Taha, M.O.; Caricati-Neto, A.; Ferreira, R.M.; Simões, M.J.; Monteiro, H.P.; Fagundes, D.J. L-arginine in the ischemic phase protects against liver ischemia-reperfusion injury. Acta Cir. Bras. 2012, 27, 616-623. [CrossRef]

130. Tang, P.C.; Ng, Y.F.; Ho, S.; Gyda, M.; Chan, S.W. Resveratrol and cardiovascular health-promising therapeutic or hopeless illusion. Pharmacol. Res. 2014, 90, 88-115. [CrossRef]

131. Magyar, K.; Halmosi, R.; Palfi, A.; Feher, G.; Czopf, L.; Fulop, A.; Battyany, I.; Sumegi, B.; Toth, K.; Szabados, E. Cardioprotection by resveratrol: A human clinical trial in patients with stable coronary artery disease. Clin. Hemortheol. Microcirc. 2012, 50, 179-187.

132. Mukherjee, S.; Dudley, J.I.; Das, D.K. Dose-dependency of resveratrol in providing health benefits. Dose Response 2010, 8, 478-500. [CrossRef]

133. Li, T.; Chen, L.; Yu, Y.; Yang, B.; Li, P.; Tan, X.Q. Resveratrol alleviates hypoxia/reoxygenation injury-induced mitochondrial oxidative stress in cardiomyocytes. Mol. Med. Rep. 2019. [CrossRef]

134. Moavahed, A.; Yu, L.; Thandapilly, S.J.; Louis, X.L.; Netticadan, T. Resveratrol protects adult cardiomyocytes against oxidative stress mediated cell injury. Arch. Biochem. Biophys. 2012, 527, 74-80. [CrossRef]

135. Fourny, N.; Lan, C.; Seree, E.; Bernard, M.; Desrois, M. Protective effect of resveratrol against ischemia-reperfusion injury via enhanced high energy compounds and eNOS-SIRT1 expression in type 2 diabetic female rat heart. Nutrients 2019, 11, 105. [CrossRef]

136. Mokni, M.; Hamlaoui, S.; Karkouch, I.; Amri, M.; Marzouki, L.; Limam, F.; Aouni, E. Resveratrol provides cardioprotection after ischemia/reperfusion injury via modulation of antioxidant enzyme activities. Iran. J. Pharm. Res. 2013, 12, 867-875.

137. Song, J.; Huang, Y.; Zheng, W.; Yan, J.; Cheng, M.; Zhao, R.; Chen, L.; Hu, C.; Jia, W. Resveratrol reduces intracellular reactive oxygen species levels by inducing autophagy through the AMPK-mTOR pathway. Front. Med. 2018, 12, 697-706. [CrossRef]

138. Tian, M.; Xie, Y.; Meng, Y.; Ma, W.; Tong, Z.; Yang, X.; Lai, S.; Zhou, Y.; He, M.; Liao, Z. Resveratrol protects cardiomyocytes against anoxia/reoxygenation via dephosphorylation of VDAC1 by Akt-GSK3 $\beta$ pathway. Eur. J. Pharmacol. 2019, 843, 80-87. [CrossRef]

139. Thuc, L.C.; Teshima, Y.; Takahashi, N.; Nishio, S.; Fukai, A.; Kume, O.; Saito, S.; Nakagawa, M.; Saikawa, T. Inhibition of $\mathrm{Na}^{+}-\mathrm{H}^{+}$exchange as a mechanism of rapid cardioprotection by resveratrol. Br. J. Pharmacol. 2012, 166, 1745-1755. [CrossRef]

140. Yang, Q.; Wang, H.C.; Liu, Y.; Gao, C.; Sun, L.; Tao, L. Resveratrol cardioprotection against myocardial ischemia/reperfusion injury involves upregulation of adiponectin levels and multimerization in type 2 diabetic mice. J. Cardiovasc. Pharmacol. 2016, 68, 304-312. [CrossRef]

141. Cheung, J.Y.; Wang, J.; Zhang, X.Q.; Song, J.; Tomar, D.; Madesh, M.; Judenherc-Haouzi, A.; Haouzi, P. Methylene blue counteracts cyanide cardiotoxicity: Cellular mechanisms. J. Appl. Physiol. 2018, 124, 1164-1176. [CrossRef] 
142. Evora, P.R. Methylene blue is a guanylate cyclase inhibitor that does not interfere with nitric oxide synthesis. Tex. Heart Inst. J. 2016, 43, 103. [CrossRef]

143. Pabla, R.; Bland-Ward, P.; Moore, P.K.; Curtis, M.J. An endogenous protectant effect of cardiac cyclic GMP against reperfusion-induced ventricular fibrillation in the rat heart. Br. J. Pharmacol. 1995, 116, 2923-2930. [CrossRef]

144. Habib, A.M.; Elsherbeny, A.G.; Alemhizia, R.A. Methylene blue for vasoplegic syndrome postcardiac surgery. Indian J. Crit. Care Med. 2018, 22, 168-173. [CrossRef]

145. Haffner, S.; Taegtmeyer, H. Epidemic obesity and the metabolic syndrome. Circulation 2003, 108, 1541-1545. [CrossRef]

146. Lakka, H.M.; Laaksonen, D.E.; Lakka, T.A.; Niskanen, L.K.; Kumpusalo, E.; Tuomilehto, J.; Salonen, J.T. The metabolic syndrome and total and cardiovascular disease mortality in middleaged men. JAMA 2002, 288, 2709-2716. [CrossRef]

147. Gómez-Garre, D.; Muñoz-Pacheco, P.; González-Rubio, M.L.; Aragoncillo, P.; Granados, R.; Fernández-Cruz, A. Ezetimibe reduces plaque inflammation in a rabbit model of atherosclerosis and inhibits monocyte migration in addition to its lipid-lowering effect. Br. J. Pharmacol. 2009, 156, 1218-1227. [CrossRef]

148. Halpern, A.; Mancini, M.C. Treatment of obesity: An update on anti-obesity medications. Obes. Rev. 2003, 4, 25-42. [CrossRef]

149. Reitsma, J.B.; Cabezas, M.C.; de Bruin, T.W.; Erkelens, D.W. Relationship between improved postprandial lipemia and lowdensity lipoprotein metabolism during treatment with tetrahydrolipstatin, a pancreatic lipase inhibitor. Metabolism 1994, 43, 293-298. [CrossRef]

150. Tzotzas, T.; Krassas, G.E.; Bruckert, E. Administration of orlistat in a patient with familial hyperchylomicronemia. Atherosclerosis 2002, 165, 185-186. [CrossRef]

151. Menezes-Rodrigues, F.S.; Errante, P.R.; Ferreira, R.M.; Tavares, J.G.P.; Paula, L.; Araújo, E.A.; Govato, T.C.P.; Tikazawa, E.H.; Reis, M.C.M.; Luna-Filho, B.; et al. Cardioprotective effect of lipstatin derivate orlistat on normotensive rats submitted to cardiac ischemia and reperfusion. Acta Cir. Bras. 2018, 33, 524-532. [CrossRef]

(C) 2019 by the authors. Licensee MDPI, Basel, Switzerland. This article is an open access article distributed under the terms and conditions of the Creative Commons Attribution (CC BY) license (http://creativecommons.org/licenses/by/4.0/). 